\title{
Protective Effects of $(E)-\beta$-Caryophyllene (BCP) in Chronic Inflammation
}

\author{
Rosaria Scandiffio $^{1,2}{ }^{\mathbb{D}}$, Federica Geddo ${ }^{1}$, Erika Cottone ${ }^{1}{ }^{\mathbb{D}}$, Giulia Querio ${ }^{1}$, \\ Susanna Antoniotti ${ }^{1}$, Maria Pia Gallo ${ }^{1}$, Massimo E. Maffei ${ }^{2}$ (D) and Patrizia Bovolin ${ }^{1 \text {,* }}$ \\ 1 Department of Life Sciences and Systems Biology, University of Turin, Via Accademia Albertina 13, \\ 10123 Turin, Italy; rosaria.scandiffio@unito.it (R.S.); federica.geddo@unito.it (F.G.); \\ erika.cottone@unito.it (E.C.); giulia.querio@unito.it (G.Q.); susanna.antoniotti@unito.it (S.A.); \\ mariapia.gallo@unito.it (M.P.G.) \\ 2 Plant Physiology Unit, Department of Life Sciences and Systems Biology, University of Turin, \\ Via Quarello 15/a, 10135 Turin, Italy; massimo.maffei@unito.it \\ * Correspondence: patrizia.bovolin@unito.it
}

Received: 30 September 2020; Accepted: 21 October 2020; Published: 26 October 2020

\begin{abstract}
E)$ - $\beta$-caryophyllene $(\mathrm{BCP})$ is a bicyclic sesquiterpene widely distributed in the plant kingdom, where it contributes a unique aroma to essential oils and has a pivotal role in the survival and evolution of higher plants. Recent studies provided evidence for protective roles of BCP in animal cells, highlighting its possible use as a novel therapeutic tool. Experimental results show the ability of $\mathrm{BCP}$ to reduce pro-inflammatory mediators such as tumor necrosis factor-alfa (TNF- $\alpha$ ), interleukin-1 $\beta$ (IL-1 $\beta$ ), interleukin-6 (IL-6), nuclear factor kappa-light-chain-enhancer of activated B cells (NF- $\mathrm{kB}$ ), thus ameliorating chronic pathologies characterized by inflammation and oxidative stress, in particular metabolic and neurological diseases. Through the binding to CB2 cannabinoid receptors and the interaction with members of the family of peroxisome proliferator-activated receptors (PPARs), BCP shows beneficial effects on obesity, non-alcoholic fatty liver disease/nonalcoholic steatohepatitis (NAFLD/NASH) liver diseases, diabetes, cardiovascular diseases, pain and other nervous system disorders. This review describes the current knowledge on the biosynthesis and natural sources of $\mathrm{BCP}$, and reviews its role and mechanisms of action in different inflammation-related metabolic and neurologic disorders.
\end{abstract}

Keywords: (E)- $\beta$-caryophyllene; biosynthesis and distribution; inflammation; metabolic disorders; obesity; steatosis; type II diabetes; cardiovascular disorders; pain; neurodegenerative diseases

\section{Introduction}

The scientific interest for natural compounds as novel potential drugs has increased exponentially in the last few years, along with the number of trials and studies on nutraceuticals and herbal extracts, aimed to test their effects on many disorders, including obesity, type II diabetes (T2D), cardiovascular disease (CVD), NAFLD and also cancer [1-4].

The sesquiterpene hydrocarbon $(E)$ - $\beta$-caryophyllene $(\mathrm{BCP})$ is one of the most studied and promising natural compounds [5-10]. In recent years, modulatory and pharmacological effects of BCP have been demonstrated in numerous organs such as liver [11], kidney [12] and brain [13]. BCP has been reported to exert therapeutic effects as antioxidant [11], anti-inflammatory [14] and anticancer [12,15]. Importantly, BCP has been identified as a fully selective agonist of CB2 cannabinoid receptors [16], one of the key members of the endocannabinoid system (ECS). The ECS is an endogenous system exerting regulatory control on food intake, metabolism and storage of calories and for this reason it represents a potential pharmacotherapeutic target for a wide range of metabolic disorders such 
as obesity, dyslipidemia, steatosis, diabetes and eating disorders [17]. The ECS is also involved in the regulation of inflammation [18] and in the modulation of depression, schizophrenia and chronic pain [6,19-21]. The selectivity of $\mathrm{BCP}$ for $\mathrm{CB} 2$ receptors avoids potential psychotropic effects mediated by brain $\mathrm{CB} 1$ cannabinoid receptor, being $\mathrm{CB} 2$ receptors mainly expressed in peripheral tissues and in central nervous system (CNS) immune cells $[5,16]$. Apart from CB2 receptors, BCP has been recently demonstrated to interact with members of the family of peroxisome proliferator-activated receptors (PPARs), in particular PPAR $\alpha$ and $\gamma$, transcriptional factors belonging to the ligand-activated nuclear receptor superfamily $[10,22,23]$.

This review will first present the molecular features, biosynthesis and distribution of $\mathrm{BCP}$ in plants, followed by current information on the molecular targets of BCP in animal cells. Finally, the beneficial effects of $\mathrm{BCP}$ on human health will be discussed; since many of them have been already extensively reviewed $[5-7,9,24,25]$, this review will specifically focus on BCP effects in metabolic and neurological diseases/disorders, with special emphasis on those characterized by chronic inflammation.

\section{Plant Distribution, Biosynthesis and Molecular Biology of BCP}

$\mathrm{BCP}$, a bicyclic sesquiterpene, is widely distributed in the plant kingdom. It is a secondary metabolite belonging to the macro group of terpenes, it exerts a pivotal role in the survival and evolution of higher plants and contributes to the unique aroma of essential oils extracted from numerous species [26]. BCP is one of the most widespread sesquiterpenes in floral volatiles, occurring in more than $50 \%$ of angiosperm families [27]. A recent study identified several plants able to produce high percentages and high yields of BCP [28]. The work, out of more than 300 selected species, identified top species like Copaifera langsdforffii, Cananga odorata, Humulus lupulus, Piper nigrum and Syzygium aromaticum, which provide a high percentage of BCP along with interesting essential oil yields. These species possess a high potential for BCP utilization; however, only a skillful molecular fractionation of the essential oil allows the removal of undesired or even toxic terpenes that sometimes may be present along with BCP [28]. For instance, essential oils from S. aromaticum (also known as clove oil) may contain relatively high percentages of the toxic compound eugenol. This compound may form eugenol-quinone methides in hepatocytes, which are responsible for the cytotoxicity mediated by eugenol; finally, methyl eugenol, a derivative of eugenol, is also hepatotoxic [29]. With the due fractionation, the high percentages of $\mathrm{BCP}$ provided by these plants can be used for the preparation of new drugs or dietary supplements aimed to improve health, prevent lifestyle illnesses and act as a valid support for chronical diseases such as pain, metabolic and neurological disorders [28].

Due to the wide variety of plants producing $\mathrm{BCP}$, the chemical synthesis of $\mathrm{BCP}$ appears to be an inconvenient strategy. For instance, a chemical method for BCP synthesis required eight steps including reduction, dehydration by Mitsunobu activation, diastereoselective reduction, selective tosylation, deprotonation, carbonyl-forming elimination, desilation and wittig methylenation [30]. Another way of producing BCP could be through microbial fermentation, because microorganisms grow rapidly. Although significant BCP yields have been obtained by employing a multi-step metabolic engineering strategy to increase precursor and cofactor supplies for $\mathrm{BCP}$ production [31], the costs for biotechnological applications are still too high when compared to essential oil costs and yields.

Thus, plants remain the main factories for BCP synthesis. In plants, terpenes are synthesized by terpene synthases (TPSs) which accept the ubiquitous prenyl diphosphates geranyl diphosphate (GPP), farnesyl diphosphate (FPP) and geranylgeranyl diphosphate (GGPP) as substrates and convert them into the different mono-, sesqui- and diterpene skeletons, respectively [32]. In the biochemical pathway that leads to BCP, the five-carbon building blocks isopentenyl diphosphate (IPP) and its allylic isomer dimethylallyl diphosphate (DMAPP) originate from two alternative pathways: the cytosolic mevalonate (MVA) pathway and the plastidial methylerythritol phosphate (MEP) pathway [32]. However, there is no compartmental separation of the two pathways and the extent of this cross-talk depends on the species and the physiological conditions [33]. 
The condensation of one DMAPP and two IPP molecules catalyzed by farnesyl diphosphate synthase (FPPS) leads to the formation of farnesyl diphosphate (FPP) in the cytosol [34]. FPP serves as substrate for TPSs for synthesizing BCP and the reaction starts with FPP ionization to a trans-farnesyl cation [35]. This is then followed by a series of complex chemical mechanisms involving isomerizations, cyclizations, and rearrangements catalyzed by TPSs, which generate humulyl cation, caryophyllyl cation and eventually BCP [36] (Figure 1).

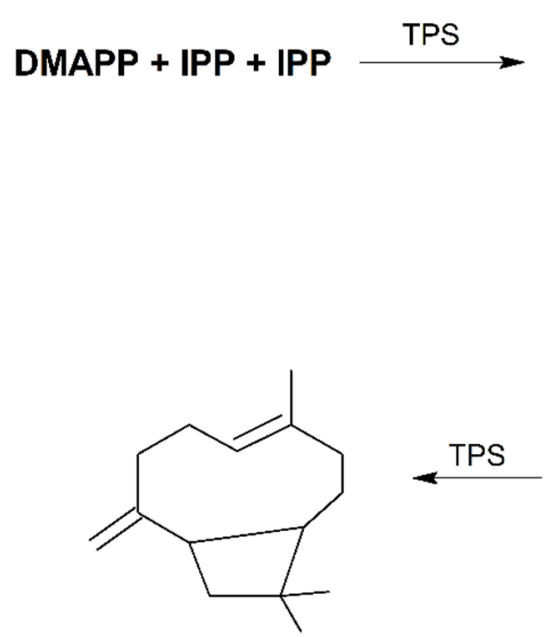

BCP<smiles>CC(C)=CCCc1cccc(C)c1</smiles>

Farnesyl diphosphate

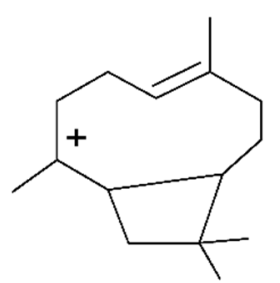

Caryophyllyl cation

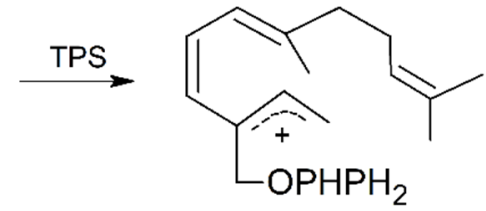

Trans-farnesyl carbocation

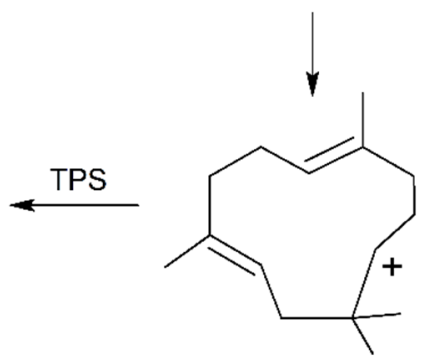

Humulyl cation

Figure 1. Simplified mechanism of the formation of $(E)-\beta$-caryophyllene (BCP) from DMAPP and IPP. Abbreviations: DMAPP, dimethylallyl diphosphate; IPP, isopentenyl diphosphate; TPS, terpene synthase. Modified from [36].

The BCP synthase (BCS) gene is characterized by the GVYXEP consensus sequence common to angiosperm sesquiterpene synthases [37], a conserved aspartate-rich region (DDxxD), which is crucial for the substrate binding [38] and by the $x \mathrm{Dx} 6 \mathrm{E}$ motif for metal cofactor binding [39]. A RR(X) $)_{8} \mathrm{~W}$ motif, which is present in the $N$-terminal region and downstream of the $N$-terminal transit peptide, is assumed to participate in the ionization of the substrate [40] and is characteristic of the majority of the members of the terpene synthase subfamilies TPS-a and TPS-b [37]. Another conserved region, the RxR motif, is located 35 amino acids upstream of the DDxxD motif and is known to form the complex of diphosphate group after substrate ionization [41].

The role of BCP in plants is directly connected to plant defense and attraction. BCP is the main product of Gossypium hirsutum terpene synthase 1 (GhTPS1) and the expression of GhTPS1 is induced in leaves of methyl jasmonate (MeJA)-treated cotton plants [42,43]. In Medicago truncatula, the MEP pathway-derived BCP is the main product of the terpene synthase 1 (MtTPS1); in this case the gene is induced by jasmonate (JA) and by the combination of JA and the ethylene precursor 1-aminocyclopropane-1-carboxylic acid (ACC) [44].

In grapevine five genes are known to code for BCP synthases [45] but only one (VvGwECar2) is actually expressed in all plant tissues and therefore accounts for most of the volatile production in vegetative parts and berries [46]. In this plant, flowers express two other genes (VvGwECar1 and VvPNECar2) that seem to play an important role in these organs [47]. Biochemical analysis of Oryza sativa terpene synthase 1 (OryzaTPS1), coded by a rice terpene synthase gene involved in indirect defense against insects, showed that the enzyme functions as a BCS [48].

A partial cDNA for the BCP synthase gene $(M m C S)$ was isolated from the expressed sequence tag (EST) library of Mikania micrantha leaves. MmCS expression was significantly increased in M. micrantha leaves within 3-days after wounding [49] and was found to be induced by high $\mathrm{CO}_{2}$ levels [50]. The Japanese pepper (Zanthoxylum piperitum) produces BCP in the secretory cavities. In this plant, 
the BCS ZpTPS1 specifically accepts the substrate FPP and is responsible for the biosynthesis of $\mathrm{BCP}$ [51]. In the flowers of the model plant Arabidopsis thaliana, the expression of terpene synthases can be induced by the phytohormones gibberellin (GA) and JA, and their induction increases the expression of TPS21, which encodes an enzyme that converts farnesyl diphosphate into BCP [52,53]. TPS21 overexpression also demonstrated that BCP served as a defense against pathogens that invade floral tissues [35]. In Liquidambar formosana, the characterization of the BCS LfTPSO4 showed that seasonal differences in BCP content were correlated to the sesquiterpene synthase gene expression [54]. Expression patterns of BCP synthase gene during the development of Artemisia annua were observed in response to wounding and elicitation [55], whereas in Pinus sylvestris (Scots pine), insect oviposition enhances the transcription of the $\mathrm{BCP} / \alpha$-humulene synthase (PsTPS1), which in turn induces the attraction of an insect parasitoid [56]. Finally, in black pepper (Piper nigrum), PnTPS1 produced BCP as a main product and $\alpha$-humulene as a minor compound. The transcript level of PnTPS1 correlated with the predominant $\mathrm{BCP}$ biosynthesis in black pepper, defining it as a relevant source of $\mathrm{BCP}$ [57].

\section{Molecular Targets of BCP Action in Animal Cells}

Apart from the functions of BCP in plants, recent studies outlined also a role of BCP in animal cells, highlighting its possible use as a novel therapeutic tool. Although the mechanism of action is not yet fully understood, studies indicate that BCP could act in animal cells through the specific binding to the CB2 receptor, a member of the endocannabinoid system [16], as well as the activation of PPARs, in particular PPAR $\alpha$ and $\gamma[10,22,23]$.

In the next few paragraphs, we will therefore describe more in detail these two classes of receptors.

\subsection{CB2 Receptors}

The cannabinoid receptors CB2 and CB1 belong to the endocannabinoid system, along with their natural ligands, the endocannabinoids, e.g., anandamide (AEA) and 2-arachidonoylglycerol (2-AG), and a plethora of enzymes involved in their biosynthesis and inactivation [58,59]. Nevertheless, exogenous cannabinoids do exist, the most potent of which is $\Delta^{9}$-tetrahydrocannabinol (THC), a well-known terpenoid present in Cannabis sativa var. indica, responsible for the psychoactive effects of marijuana [60]. The endocannabinoid system shares mediators and overlaps with metabolic processes of other signaling pathways; thus, a wider endocannabinoid-related network has been identified as "expanded endocannabinoid system" or "endocannabinoidome" [61].

Both CB1 and CB2 receptors are G-protein coupled receptors, with an extracellular $N$-terminal domain, seven transmembrane alpha-helices and an intracellular C-terminus [62,63]. They show $44 \%$ overall amino acid similarity and $68 \%$ homology in the transmembrane domain [63]; one of the most different regions is the one located in the extracellular domain, which is responsible for cannabinoid binding [64]. Both receptors signal through $\mathrm{G}_{\mathrm{i} / \mathrm{o}}$ proteins, thus they can inhibit adenylyl cyclase and activate mitogen-activated protein kinases (MAPKs). Worthy of note is the fact that MAPKs could regulate the activation of PPARs via direct phosphorylation. Differently from CB2 receptor, $\mathrm{CB} 1$-coupled $\mathrm{G}_{\mathrm{i} / \mathrm{o}}$ proteins can mediate activation of A-type and inwardly rectifying potassium channels, and inhibition of N- and P/Q-type calcium currents; in addition, CB1 receptors can signal through $\mathrm{G}_{\mathrm{s}}$ proteins [65].

CB1 is the most abundant and widespread G-protein coupled receptor in the mammalian brain, being highly expressed by presynaptic termini of neurons in the cortex, amygdala, hippocampus, basal ganglia, and cerebellum, where its activation modulates neurotransmitter release [66]. Notably, CB1 is present also in many peripheral sites, including spleen, lung, thymus, heart [67].

On the other hand, CB2 receptors, are mostly distributed peripherally, in the cells of the immune system [68] and indeed the main role of CB2 seems to be immune modulation. However, recent studies showed low levels of CB2 also in the central nervous system [69], especially in microglial cells and its activation in association with neurodegenerative disorders [70]. 
The endocannabinoid system, due to its wide distribution, regulates various physiological functions, such as neurogenesis and neurodegeneration, cognitive and mood regulation, appetite and metabolism, muscle contractility, inflammation and immune functions [67].

In 2008, Gertsch and colleagues [16] showed that BCP is able to elicit some of its effects by acting as a fully functional agonist of the $\mathrm{CB} 2$ receptor. Notably, $\mathrm{BCP}$ binds selectively $\mathrm{CB} 2$ receptors, since it lacks significant binding activity to the human CB1 (hCB1) receptor, and it is unable to displace high-affinity ligands from hCB1. BCP was shown to bind hCB2 with an inhibitory constant $\mathrm{K}_{\mathrm{i}}$ of $155 \pm 4 \mathrm{nM}$, a binding affinity about 150 times lower than the potent high affinity cannabinoid ligand WIN55,212-2 (whose $K_{i}$ for hCB2 is $1.2 \mathrm{nM}$ ). BCP, likely in its bioactive $\beta \beta$ conformation, binds to the hydrophobic region of the amphipathic hCB2 receptor binding pocket, being the putative binding site located adjacent to helices III, V, VI, and VII at the near extracellular site of the seven transmembrane domain. BCP acts as a full CB2 receptor ligand, since its binding activates CB2-mediated intracellular signaling, e.g., adenylate cyclase inhibition, intracellular calcium release and mitogen-activated kinases Erk1/2 and p38 activation [16]. Notably, BCP was shown to lead to anti-inflammatory effects, inhibiting lipopolysaccharide (LPS)-induced TNF and IL-1 $\beta$ expression in peripheral blood and attenuating LPS-stimulated Erk1/2 and JNK1/2 phosphorylation in monocytes. CB2-mediated BCP anti-inflammatory effects were also observed in an in vivo model, where BCP ( 5 and $10 \mathrm{mg} / \mathrm{kg}$ body weight), orally administered $1 \mathrm{~h}$ before carrageenan treatment, strongly reduces inflammatory response in wild-type mice but not in CB2 deficient mice [16].

Recent studies have demonstrated a role of $\mathrm{BCP}$, through the activation of $\mathrm{CB} 2$ receptors, in the modulation of different processes. A specific $\mathrm{BCP}$-mediated $\mathrm{CB} 2$ receptor activation has been demonstrated to be at the base for example of tumor suppression in glioblastoma where it has anti-proliferative effects and plays an anti-inflammatory activity through the modulation of NF- $\mathrm{KB}$ and PPAR $\gamma$ [71]. In LPS-induced interstitial cystitis in mice, the intravesical instillation or the oral treatment with $\mathrm{BCP}(100 \mathrm{mg} / \mathrm{kg})$ resulted in a significant decrease in the number of adherent leukocytes, thus confirming an anti-inflammatory activity in bladder inflammation [72]. In another study [73], BCP $(25 \mathrm{mg} / \mathrm{kg})$ was able to prevent nucleoside reverse transcriptase inhibitors (NRTI)-induced neuropathic pain in mice, in a CB2 cannabinoid receptor-dependent manner; also, BCP treatment prevented the induced upregulation of inflammatory cytokines mRNA transcripts (i.e., Interferon $\gamma$, IL-6 $\beta$ and $\mathrm{TNF} \alpha)$.

\subsection{PPARs}

PPARs are transcriptional factors belonging to the ligand-activated nuclear receptor superfamily involved in both metabolic and inflammatory responses (recently reviewed by Hong et al. [74]). The existence of receptors that could mediate peroxisome proliferation was first hypothesized in 1983 by Lalwani et al. [75]. PPAR $\alpha$ (also called NR1C1) was later identified [76] as a new member of the steroid hormone receptor superfamily, that could be activated by different molecules, such as fatty acids and fibrates, a widely used class of hypolipidemic drugs. Further on, other members of PPARs family were discovered [77], namely PPAR $\beta / \delta$ (NR1C2) and PPAR $\gamma$ (NR1C3). PPAR $\beta / \delta$ is activated by saturated and polyunsaturated fatty acids and eicosanoids, as well as synthetic ligands. PPAR $\gamma$ is instead a specific receptor for thiazolidinediones (TZDs), such as troglitazone, rosiglitazone and pioglitazone, widely used for T2D treatment [74].

Although PPARs share high structural homologies, they are encoded by different genes, have different ligands, are expressed in different tissues and regulate different biological processes [74].

PPAR $\alpha$ is abundantly expressed in the liver, where it acts as the master regulator of hepatic lipid metabolism [10,78,79]. PPAR $\alpha$ is also present in the brown adipose tissue, heart, kidney and muscles [80]. PPAR $\beta / \delta$ is expressed in skeletal muscle, heart, gastrointestinal tract, adipose tissue, where it regulates fatty acid metabolism [81]. PPAR $\gamma$ is actually considered the master gene of adipogenesis, being mostly expressed in white and brown adipose tissue, but also the large intestine and the spleen $[10,82]$. Two major PPAR $\gamma$ isoforms, derived from alternative promoter usage, have been described. While 
PPAR $\gamma 1$ is expressed in many different tissues, PPAR $\gamma 2$ is specifically expressed in adipose tissue, although it can be induced in other districts by a high-fat diet $[83,84]$. PPAR $\gamma$ participates into the programmed differentiation of adipocytes by enhancing the $5^{\prime}$-adenosine monophosphate-activated protein kinase (AMPK) activity, a master energy sensor which regulates diverse metabolic pathways, increases mitochondrial activity and biogenesis in muscles and is responsible for the inhibition of adipogenesis [9,85]; moreover, PPAR $\gamma$ is an insulin sensitizer also involved in glucose homeostasis [74].

PPARs are ligand-activated nuclear receptors, that enhance the transcription of specific genes. They are characterized by 13 helices and a small four beta-sheets with a large hydrophobic binding pocket. Ligand binding induces a conformational change of the ligand-binding region and allow PPARs to form heterodimers with the retinoid-X-receptor (RXR); after activation, PPAR-RXR heterodimers can bind to specific DNA sequences (PPAR response elements, PPREs), which in turn stimulate the transcription of target genes [86]. The function of PPARs can be stimulated by the presence of specific coactivators or inhibited by corepressors, depending on the different tissues [87].

$\mathrm{BCP}$ has been demonstrated to interact with and to up-regulate members of the PPARs family. In particular, it can activate $\operatorname{PPAR} \alpha$ through a direct interaction with the ligand-binding pocket, thus regulating lipid metabolism [23].

Furthermore, studies indicate the triggering of PPAR $\gamma$ via a BCP-mediated CB2 receptor activation [88,89]. In this respect, PPAR $\gamma$ was demonstrated to be involved in BCP-dependent neuroprotection [90] and tumor suppression functions [71], as well as hypolipidemic effects and vascular inflammation amelioration [10], anxiolytic, anti-oxidant, anti-arthritic and anti-inflammatory effects [22,48,91].

\section{Protective Effects of BCP on Metabolic and Neural Disorders Characterized by Inflammatory States}

Recently, a growing number of studies has described multiple protective effects of BCP in several metabolic and neural disorders. Notably, these disorders are mostly characterized by chronic inflammation. In the next subsections, first the general features of chronic inflammation will be presented, followed by description of the protective and anti-inflammatory effects exerted by BCP in specific metabolic and neurologic diseases.

\subsection{Chronic Inflammation as a Common Theme of Many Metabolic and Neurological Disorders}

During the last decades, the complex phenomenon of inflammation has been extensively studied, and it has become clear that this condition is a fundamental feature of metabolic disorders such as obesity, type II diabetes (T2D), nonalcoholic steatohepatitis (NASH), NAFLD [92-95] and also neurological disorders, e.g., chronic pain, Parkinson's and Alzheimer's diseases [21,96,97].

The process of inflammation constitutes the tissue response to injury, and can be divided into acute and chronic inflammation. The first one is characterized by increased blood flow and vascular permeability, along with accumulation of inflammatory mediators such as cytokines, and immune cells, like neutrophils. The resolution of acute inflammation occurs rapidly [98]. Chronic inflammation involves progressive changes in inflammatory cells and the coexistence of tissue destruction and repair; it can become pathological because of the loss of tolerance or regulatory processes. Obesity and metabolic syndrome lead to an inflammatory state that differ from the classical response, being the inflammatory process systemic and characterized by a chronic low-intensity reaction [99]. During the first stages of white adipose tissue expansion, typical of an overweight condition, a set of acute pro-inflammatory mediators is required to support the remodeling of healthy adipose depots; however, if lipid accumulation progresses and the pro-inflammatory molecules persist, a state of chronic low-level inflammation is established, a typical scenario of an obesity condition. Recent studies showed that local infiltration of immune cells and enhanced production of pro-inflammatory cytokines lead to a condition that could generate insulin resistance, defective insulin secretion, and disruption of other aspects of energy homeostasis $[93,94,100]$. This chronic, low-grade, metabolically triggered inflammation is also 
called metaflammation, a condition mainly generated by metabolic excess and occurring in several metabolic tissues, including adipose tissue, pancreas, liver, muscle, brain, and heart [101-103].

The chronic inflammatory response develops from the interaction between adipose tissue resident immune cells, including macrophages, and the immune system, skewed to a proinflammatory phenotype. Under physiological conditions, immune cells coordinately regulate tissue integrity and metabolism by controlling the activity of subsets of $\mathrm{T}$ lymphocytes. These cells release a cascade of cytokines that regulate other immune cells such as mast cells, eosinophils and others, maintaining resident macrophages in a M2-polarized phenotype, therefore acting toward an anti-inflammatory and immunoregulatory direction [94,104].

Conversely, under pathological conditions like obesity, fatty liver disease and T2D, immune cells withstand changes such as the recruitment of M1-polarized macrophages, which display a more proinflammatory phenotype and secrete proinflammatory cytokines such as TNF- $\alpha$,IL-1, IL-6, IL-12 and C-reactive protein [94,105-107].

The hypothesis that inflammation is linked to metabolic conditions was formulated in 1993 with the publication by Hotamisligil and colleagues, demonstrating that adipocytes constitutively express TNF- $\alpha$, whose expression is noticeably increased in adipocytes of obese animal models (ob/ob mouse, $\mathrm{db} / \mathrm{db}$ mouse and fa/fa Zucker rat) [108,109]. Nowadays, almost 30 years later, the link between obesity, diabetes and chronic inflammation has been confirmed $[93,109]$ and it has been also proved that mice lacking functional TNF- $\alpha$ are more insulin sensitive and glucose tolerant than wild type animals [106,110]. Moreover, TNF- $\alpha$ is overexpressed in the adipose and muscle tissues of obese humans, and its exogenous dragging leads to insulin resistance [92,111].

Metabolic, inflammatory and innate immune processes are also regulated by lipids [92,112] through the action of PPARs and liver X receptor (LXR) families. Activation of these transcription factors inhibits the expression of several genes involved in the inflammatory response in macrophages and adipocytes, therefore suppressing the production of proinflammatory cytokines $[92,113,114]$.

In this complex scenario, the Toll-Like receptor (TLRs) pathway plays a crucial role; in fact, it has been demonstrated that fatty acids may also bind to Toll-like receptors, inducing the synthesis of inflammatory markers in macrophages and exacerbating insulin resistance [107,115]. TLRs are a family of transmembrane receptors that recognize a variety of pathogen-associated molecular patterns (PAMPs), playing a fundamental role in the innate immune system. Presumably reflecting structural similarity between microbial and host membrane lipids, the subfamily of TLR2 and TLR4 have been reported also to recognize select host lipids and to play important roles in the pathogenesis of insulin resistance and obesity $[99,115]$.

Hypertrophic obesity leads to a dysregulated subcutaneous adipose tissue and the accumulation of ectopic fat in many depots, such as in liver, where inflammation and hepatocyte injury are the hallmarks of NASH and NAFLD $[95,116]$. The innate immune system plays a fundamental role also in triggering and amplifying hepatic inflammation in liver lipid disorders. Activation of the inflammatory response pathway results from abnormal accumulation of lipids and consequent lipotoxicity [95]. It has been demonstrated that PPAR $\alpha$ plays central role in this context, exerting anti-inflammatory activities in murine models of systemic inflammation. In fact, PPAR $\alpha$ agonists specifically attenuate IL-6 concentration in vitro and in vivo $[117,118]$.

Inflammatory reaction can also occur in chronic nervous system diseases, being neuroinflammation a central pathological feature of several neurological disorders such as Alzheimer's disease, Parkinson's disease and multiple sclerosis. Acting as a mediator in neurodegenerative pathologies, neuroinflammation causes microglia activation, mitochondrial dysfunction, as well as release of pro-inflammatory cytokines and reactive oxygen species (ROS) production [119].

\subsection{Protective Effects of BCP on Metabolic Disorders Characterized by Chronic Inflammation}

The current increase in metabolic diseases such as obesity, T2D, liver lipid disorders, and the complex framework of metabolic syndrome (MetS) is now considered a sort of epidemics caused by 
multiple factors, including loss of exercise, aging, wrong diet, genetic background and exposure to endocrine disruptors [120-122]. Most single metabolic diseases and complex syndromes such as MetS are characterized by inflammation, often becoming chronic and leading to CVD [123-125].

To cope with this global complex problem, several strategies are needed. Thanks to the growing data in this field, natural compounds are becoming an important approach to promote health and ameliorate metabolic disorder conditions [1,123,126-130].

Recently, a growing number of reports has described multiple protective effects of $\mathrm{BCP}$ in several metabolic disorders (see Table 1). In particular, $\mathrm{BCP}$ has been shown to actively promote the inhibition of lipid accumulation, fatty acids oxidation, decrease of visceral fat index, reduction of total cholesterol, triglycerides, and low density lipoprotein (LDL) cholesterol levels, decrease of hepatic 3-hydroxy-3-methylglutayl coenzyme A (HMG-CoA) reductase activity, reduction of body weight in animal models and action as insulinotropic agent [5,10,78,126,131-136]. Notably, the effectiveness of $\mathrm{BCP}$ as anti-inflammatory agent is at least partly due to its ability to inhibit the main inflammatory mediators, e.g., inducible nitric oxide synthase (iNOS), IL-1 $\beta$, IL-6, TNF- $\alpha$, NF- $\mathrm{kB}$, cyclooxygenase 1 (COX-1) and cyclooxygenase 2 (COX-2) [5,10,16,137].

The next subsections will describe the current knowledge about $\mathrm{BCP}$ action in different inflammation-related metabolic diseases. 
Table 1. Evidence of a role of BCP on metabolic diseases.

\begin{tabular}{|c|c|c|c|c|}
\hline Disease & Main Metabolic Effect & Experimental Model & BCP Administration & References \\
\hline \multirow{6}{*}{ Obesity and dyslipidemia } & Decrease of visceral fat index. LDL and VLDL & Wistar rats fed with HFFD & $30 \mathrm{mg} / \mathrm{Kg}$ b.w./day for 4 weeks by oral gavage & [10] \\
\hline & Inhibition of adipogenesis & Bone marrow cells & $0.1-100 \mu \mathrm{M}$ for 3-4 days in differentiation medium & [85] \\
\hline & \multirow{2}{*}{ Inhibition of lipid accumulation } & \multirow{2}{*}{ Preadipocytes (3T3-L1 cells) } & $1 \mathrm{nM}-10 \mu \mathrm{M}$ for 9 days in differentiation medium & [133] \\
\hline & & & 5 or $10 \mu \mathrm{M}$ for 6 days in differentiation medium & [134] \\
\hline & \multirow{2}{*}{ Suppression of body weight gain } & \multirow[b]{2}{*}{ HFD-fed C57BL/6N mice } & $0.15 \%$ or $0.3 \%$ supplemented diets for 16 weeks & [134] \\
\hline & & & $\begin{array}{l}0.02 \% \text { or } 0.2 \% \text { supplemented diets for } 4 \text { and } 8 \\
\text { weeks }\end{array}$ & [136] \\
\hline \multirow{6}{*}{ Hepatic steatosis } & \multirow{2}{*}{$\begin{array}{l}\text { Reduction of total cholesterol, triglycerides, and LDL } \\
\text { cholesterol levels }\end{array}$} & \multirow{2}{*}{ Hypercholesterolemic Wistar rats } & $1 \mathrm{~mL} / \mathrm{Kg}$ b.w. for 3 days by oral gavage & [126] \\
\hline & & & $30 \mathrm{mg} / \mathrm{Kg}$ b.w./day for 4 weeks by oral gavage & [135] \\
\hline & \multirow{2}{*}{ Decrease of hepatic HMG-CoA reductase activity } & \multirow{2}{*}{ Hypercholesterolemic Wistar rats } & $1 \mathrm{~mL} / \mathrm{Kg}$ b.w. for 3 days by oral gavage & [126] \\
\hline & & & $30 \mathrm{mg} / \mathrm{Kg}$ b.w./day for 4 weeks by oral gavage & [135] \\
\hline & \multirow{2}{*}{$\begin{array}{l}\text { Inhibition of palmitate-inducible lipid accumulation } \\
\text { Downregulation of FAS and upregulation of ATGL } \\
\text { Reduction of triglycerides. increase of FFA uptake and } \\
\text { FFA oxidation }\end{array}$} & \multirow{2}{*}{ Human hepatocyte cell line (HepG2) } & $5 \mu \mathrm{M}$ for $24 \mathrm{~h}$ in serum free medium & [78] \\
\hline & & & $\begin{array}{l}1,10 \text { or } 100 \mu \mathrm{M} \\
\text { for } 24 \mathrm{~h}\end{array}$ & [23] \\
\hline \multirow{3}{*}{ T2D } & Increase of glucose uptake and GLUT4 translocation & Skeletal myotubes ( $\mathrm{C} 2 \mathrm{C} 12$ cells) & $\begin{array}{l}1,10,100 \mathrm{nM} \text { for } 30 \mathrm{~min} \text { in glucose and serum free } \\
\text { medium }\end{array}$ & [133] \\
\hline & $\begin{array}{l}\text { Decrease of blood glucose levels and proinflammatory } \\
\text { cytokines levels } \\
\text { Increase of plasma insulin }\end{array}$ & Streptozotocin-Induced Diabetic rats & $200 \mathrm{mg} / \mathrm{Kg}$ b.w. for 45 days by oral gavage & {$[138,139]$} \\
\hline & Decrease of fasting blood glucose and fasting insulin & Wistar rats fed with a HFFD & $30 \mathrm{mg} / \mathrm{Kg}$ b.w./day for 4 weeks by oral gavage & [10] \\
\hline \multirow{4}{*}{$\begin{array}{l}\text { Cardiovascular } \\
\text { disorders }\end{array}$} & Reduction of atherogenic and coronary risk index & Hypercholesterolemic Wistar rats & $30 \mathrm{mg} / \mathrm{Kg}$ b.w./day for 4 weeks by oral gavage & [10] \\
\hline & $\begin{array}{l}\text { Protective role against isoproterenol-induced } \\
\text { myocardial infarction }\end{array}$ & Male Sprague-Dawley rats & 100 or $200 \mathrm{mg} / \mathrm{Kg}$ b.w/day for 21 days orally & [140] \\
\hline & \multirow{2}{*}{$\begin{array}{l}\text { Protective effect against Doxorubicin-induced } \\
\text { inflammation in the myocardium }\end{array}$} & \multirow{2}{*}{ Male Wistar Rats } & $\begin{array}{l}25,50,100 \mathrm{mg} / \mathrm{Kg} \text { b.w. for } 5 \text { days by } \\
\text { intraperitoneal injection }\end{array}$ & [141] \\
\hline & & & $\begin{array}{l}25 \mathrm{mg} / \mathrm{Kg} \text { b.w. for } 6 \text { days a week for } 5 \text { weeks by } \\
\text { intraperitoneal injection }\end{array}$ & [142] \\
\hline
\end{tabular}

HFFD: high fat/fructose diet; HFD: high fat diet; LDL: low density lipoprotein; HMG-CoA: Hydroxy methylglutaryl-Coenzyme A; FAS: fatty acid synthase; ATGL: adipose triglyceride lipase; GLUT4: glucose transporter 4; VLDL: very low density lipoprotein; FFA: free fatty acids. 


\subsubsection{Obesity and Dyslipidemia}

Obesity is a chronic metabolic disease characterized by excessive fat accumulation in adipose tissue [129]. The prevalence of obesity has increased globally over the last two decades [125], as a consequence of our evolutionary history [143]. Obesity is a multifactorial disease, caused by interactions between environment, lifestyle and genetics. Comprehension of these multiple factors is still ongoing and necessary for developing efficient strategies for obesity prevention and treatment [122].

According to the World Health Organization's report dated April 2020, worldwide obesity has nearly tripled since 1975. In 2016, more than 1.9 billion adults were overweight; of these, over 650 million were obese. Moreover, in 2019 an estimated 38.2 million children under the age of 5 were overweight or obese. Once considered a problem only for high-income countries, overweight and obesity are now on the rise in low- and middle-income countries, particularly in urban settings. In Africa, the number of overweight children under 5 has increased by nearly $24 \%$ percent since 2000 . Almost half of the children under 5 who were overweight or obese in 2019 lived in Asia [144].

Obesity correlates with cardiovascular risk, since it is associated with increased fasting plasma triglycerides and low density lipoprotein (LDL) cholesterol, low levels of high density lipoprotein (HDL) cholesterol, elevated blood glucose and insulin levels, and high blood pressure [145]. Specifically, the elevation of lipids in the blood is a condition called dyslipidemia, nowadays considered the major risk factor for the development of atherosclerotic disease and subsequent cardiovascular disease [146,147].

As mentioned before, obesity and overweight are characterized by chronic, low-grade inflammation, which perpetuates the disease and is associated with multiple complications [148], including the increase of inflammatory markers in liver, adipose tissue, skeletal muscle, pancreatic islets, and brain. Although the relationships between these events in rodents or obese humans remain poorly understood [94], in the last few years it has been suggested that adipocyte dysfunction is the trigger of obesity-related inflammation [149].

Several studies have been focused on possible strategies to treat obesity. Among the approaches based on natural compounds and bioactive molecules, the use of BCP has been tested both in vivo and in vitro. In this regard, we recently demonstrated an in vitro anti-obesogenic effect of $1 \mathrm{nM}-10 \mu \mathrm{M}$ BCP extracted from Piper nigrum and showed that it was able to reduce intracellular triglycerides accumulation without interfering with adipocyte number in the murine 3T3-L1 adipocytes [133]. The same in vitro model was already used to prove that dietary 5 or $10 \mu \mathrm{M} \mathrm{BCP}$ inhibits lipid accumulation in adipocytes and $0.15 \%-0.3 \%$ BCP dietary supplementation suppresses in vivo body weight gain and fasting blood glucose levels in high fat diet (HFD)-fed mice [134].

Another in vitro study tested the effects of $0.1-100 \mu \mathrm{M}$ BCP on osteoblastic mineralization, osteoclastogenesis and adipogenesis in a bone marrow mesenchymal stem cells (MSC) model, demonstrating that BCP significantly suppresses the differentiation of bone marrow cells into adipocytes in a dose-dependent manner [85]. In an in vivo experiment on Wistar rats fed with high fat/fructose diet (HFFD), the effect of $30 \mathrm{mg} / \mathrm{Kg}$ b.w. /day BCP administration for 4 weeks by oral gavage on diet-induced dyslipidemia and inflammation was assessed [10]. In this study, BCP was able to decrease the visceral fat index, total cholesterol, LDL, very low density lipoprotein (VLDL), and pro-inflammatory cytokines (TNF- $\alpha$ and NF-kB). These effects were reversed by treatment with CB2 and PPAR- $\gamma$ antagonists, suggesting that $\mathrm{BCP}$ activity is mediated by direct binding to $\mathrm{CB} 2$ receptors and by the activation of PPAR- $\gamma$, possibly through a cross-talk between these two receptor systems [10].

The effect of BCP on hypercholesterolemia was tested in a rat model of Triton-induced hyperlipidemia; $30 \mathrm{mg} / \mathrm{Kg}$ b.w. BCP was found to reduce total cholesterol, triglycerides, and LDL cholesterol levels in hypercholesterolemic animals and to exert hypolipidemic effects via inhibition of the hepatic HMG-CoA reductase [126]. The hypocholesterolemic effect of $30 \mathrm{mg} / \mathrm{Kg}$ b.w. BCP was also demonstrated in rats fed with cholesterol and fat enriched diet (HCFD); a significant decrease in serum total cholesterol and LDL, and an increase in HDL levels were observed also in this case [135]. 
In a mouse model of nonalcoholic steatohepatitis, $0.02 \%$ and $0.2 \% \mathrm{BCP}$ supplementation in the diet exerted an antioxidant action and reduced hepatic steatosis as well as liver inflammation and fibrosis [136].

\subsubsection{NAFLD and NASH}

Liver diseases are among the major causes of illness worldwide, and are caused by viral infections, alcohol abuse, abnormal dietary fat ingestion. In particular, NAFLD and the consequent NASH are considered as hepatic manifestation of MetS and strictly correlate with insulin resistance, obesity, dyslipidemia, atherosclerosis, and hypertension [116,150,151]. NAFLD is characterized by excess accumulation of triglycerides in hepatocytes due to both increased ingestion of free fatty acids (FFAs) and de novo hepatic lipogenesis. The accumulation of lipids causes oxidative stress and inflammatory response leading to NASH, which may progress to cirrhosis and liver cancer $[78,116,150]$.

There is multiple scientific evidence on the beneficial effects of BCP on NAFLD and NASH experimental models. Clove extract $(5 \mu \mathrm{M})$ was demonstrated to potently suppress the palmitate-induced lipid accumulation in human HepG2 hepatocytes, used as a model of in vitro NAFLD [78]. The major active molecule was found to be BCP, exerting its effects by binding to CB2 receptors, with subsequent AMPK phosphorylation, which in turn led to the upregulation of the lipolytic enzyme adipose triglyceride lipase (ATGL) and the downregulation of the lipogenic enzyme fatty acid synthase (FAS). In another in vitro study on HepG2 cells, BCP stimulation $(1,10$ or $100 \mu \mathrm{M})$ led to a significant reduction of intracellular triglycerides and an increase of hepatic FFA uptake and FFA oxidation, via a PPAR $\alpha$-dependent mechanism [23].

In hypercholesterolemic Wistar rats fed with high cholesterol and fat diet, $1 \mathrm{~mL} / \mathrm{Kg}$ b.w. or $30 \mathrm{mg} / \mathrm{Kg}$ b.w. BCP administration correlated with decreased hepatomegaly, lower hepatic lipid accumulation and steatosis, and decreased aspartate aminotransferase (AST) and alanine aminotransferase (ALT) activities; the hypolipidemic effects were mediated through inhibition of the hepatic HMG-CoA reductase $[126,135]$.

In mice fed with methionine- and choline-deficient diet (MCD) reproducing the histopathological features of human NASH, BCP administration ( $0.2 \%$ of total diet for 8 weeks) exerted beneficial effects against hepatic steatosis, liver damage and inflammation found in the development and progression of NASH [136].

\subsubsection{Diabetes}

T2D is considered one of the most important chronic diseases with severe complications, responsible for elevated indexes of morbidity and mortality [152]. The combination of genetic factors associated with impaired insulin secretion, insulin resistance, environmental factors, including overeating, aging, obesity and lack of exercise, typically accounts for T2D [153]. Moreover, insulin resistance can be a consequence of a reduction of insulin receptors numbers or a failure in insulin-receptor binding or in glucose transportation into the cell by the glucose transporter GLUT4 [152]. Inflammatory pathways have been suggested as the underlying and unifying pathogenic mediators for obesity and diabetes mellitus [154]. Indeed, an increase in body weight results in a dysfunction of the adipose tissue, with a greater release of proinflammatory cytokines, such as IL- 6 and TNF- $\alpha$. These molecules, together with increased FFA, can alter insulin sensitivity by stimulating the phosphorylation of serine instead of tyrosine residues in insulin receptor substrate-1 (IRS-1), thereby preventing the activation of insulin signaling pathway and making tissues less responsive to its action until insulin resistance [152,155].

Both in vivo and in vitro studies suggested a potential impact BCP on glucose metabolism. In particular, by in vitro analysis in skeletal myotubes (C2C12 cells) we demonstrated that 1,10 and $100 \mathrm{nM}$ of BCP was as efficient as insulin in stimulating cellular glucose uptake [133]. Besides, BCP induced the translocation of the GLUT4 storage vesicles to the plasma membrane of $\mathrm{C} 2 \mathrm{C} 12$ cells, a process that, mainly in skeletal muscle and in adipose tissue, is directly correlated with the ability to lower elevated blood glucose levels. Other studies demonstrated that BCP induces insulin secretion in 
rat insulinoma (RIN-5F cells) [131], and in mouse pancreatic $\beta$-(MIN) cell line, through activation of CB2 and small G proteins ADP ribosylation factor (Arf)6, Ras-related C3 botulinum toxin substrate (Rac) 1 and Cell division control protein (Cdc) 42 [156].

In streptozotocin (STZ)-induced diabetic rats ( $40 \mathrm{mg} / \mathrm{Kg}$ b.w.), the oral administration of $200 \mathrm{mg} / \mathrm{Kg}$ b.w. BCP significantly decreased blood glucose levels and increased plasma insulin; BCP increased the activity of metabolic enzymes such as hexokinase, pyruvate kinase and glucose-6-phosphate dehydrogenase in liver, kidney and skeletal muscle; $\mathrm{BCP}$ also reversed the activity of gluconeogenic enzymes that are deficient in diabetic rats, proving that it could normalize carbohydrate metabolism by enhancing glucose utilization and decreasing hepatic glucose production. Immunohistochemical analysis of pancreas sections demonstrated that BCP treatment improved tissue structure and increased insulin-secreting cell number, suggesting an insulinotropic effect of BCP [138]. In another study, oral administration of $200 \mathrm{mg} / \mathrm{Kg}$ b.w. BCP to STZ-induced diabetic rats significantly improved the levels of antioxidant enzymes, decreased lipid peroxidative markers in plasma and pancreatic tissues and reversed proinflammatory cytokines (TNF- $\alpha$ and IL-6) to near normal levels, thus indicating a relevant anti-inflammatory role of $\mathrm{BCP}$ in preventing diabetes-induced oxidative stress and associated complications [139].

An ex vivo and in vivo study in diabetic rats, also suggested an antidiabetic effect of $\mathrm{BCP}$ alone or in combination with dietary supplementation of L-arginine, that displays pancreatic $\beta$ cell regenerative effects through nitric oxide (NO) modulation [131].

The protective effects of $30 \mathrm{mg} / \mathrm{Kg}$ b.w. BCP treatment on metabolic alterations were also highlighted in rats receiving a high fat/fructose diet (HFFD) that causes insulin resistance and obesity, where $\mathrm{BCP}$ administration prevented HFFD-induced elevation of adipose-index, hyperglycemia and hyperinsulinemia, acting through the activation of CB2 receptors [10].

\subsubsection{Cardiovascular Disorders}

Metabolic dysfunctions are strictly related to cardiovascular inflammatory responses [157]. In particular, diet-induced disorders augment atherogenic complications and exacerbate vascular inflammation, leading to several detrimental outcomes as vascular wall thickness, platelet activation and predisposition to thrombosis $[158,159]$. This atherosclerotic process underlies ischemic diseases, among which myocardial infarction, the leading cause of death worldwide. Current established therapeutic options to prevent and treat atherosclerosis include inhibitors of cholesterol synthesis (statins), inhibitors of fat breakdown in adipose tissue (niacin), inhibitors of platelet aggregation (aspirin) and antihypertensive drugs ( $\beta$-blockers, renin-angiotensin system inhibitors) [160].

Among new experimental strategies, the use of plant-derived bioactive compounds, in combination with drugs or used as preventive intervention from early life, represents a promising approach. Anti-atherosclerotic properties have been shown by several bioactive compounds, such as Omega-3 fatty acids, phytosterols, phenolic compounds [161], and, very recently, BCP. In particular the role of $\mathrm{BCP}$ in the regulation of the inflammatory cascade has been investigated in order to evaluate its use as a therapeutic agent against cardiovascular damage. In this regard, rats fed with a high fat/high fructose diet showed an ameliorated lipid profile (higher levels of HDL and lower levels of triglycerides, total cholesterol, LDL and VLDL) when supplemented with BCP. Furthermore, $30 \mathrm{mg} / \mathrm{Kg}$ b.w. BCP induced a reduction in pro-inflammatory cytokines TNF- $\alpha$ and NF-kB and no expression of adhesion molecule vascular cell adhesion molecule (VCAM)-1 in the aorta, underlining a positive effect of the molecule against atherosclerotic burden [10]. Furthermore, oral administration of BCP to hypercholesterolemic rats reduces atherogenic index and coronary risk index, preventing cardiovascular damage $[10,162]$.

Occlusion of vascular wall could be a possible exacerbation of atherosclerosis, thus causing ischemic tissue damage with improper tissue blood supply. When the heart is involved in prolonged ischemic condition, myocardial infarction can develop, thus causing loss of cardiac cells and impaired organ function. Younis and colleagues showed the protective role of 100 or $200 \mathrm{mg} / \mathrm{Kg}$ b.w. BCP against 
isoproterenol-induced myocardial infarction, underlining the reduction of the inflammatory response induced by the treatment through a CB2-independent pathway. Indeed, orally administered BCP inactivated the heat shock protein (HSP)-60/Toll-like Receptor (TLR)/ Myeloid differentiation primary response $(\mathrm{MyD})$ 88/NF-kB pathway thus protecting the heart from pro-inflammatory cytokines and chemokines rising and reducing infarct size [140].

Among drug-mediated cardiotoxic inflammation, the deleterious effect of doxorubicin, an anthracycline used in chemotherapy, has been underlined. Doxorubicin treatment induced the expression of NF-kB and activation of pro-inflammatory cytokines and chemokines that are involved in the progression of the inflammatory response in the cardiac tissue [163]. Intraperitoneal injection of $25-100 \mathrm{mg} / \mathrm{Kg}$ b.w. BCP showed protective effects against doxorubicin toxicity, in fact, it reduced the expression of NF-kB, TNF- $\alpha$, IL-1 $\beta$ and IL-6, and down-regulated COX-2 and iNOS, thus attenuating inflammatory response in the myocardium without altering the antitumor effect of the drug and suggesting the possible use of BCP to prevent cardiac damage induced by doxorubicin [141,142].

\subsection{Activity of BCP in Pain and Other Nervous System Disorders}

Acute and especially chronic pain is a serious social burden and it has been estimated that around $10 \%$ of population worldwide suffers from long-lasting pain [164]. The neuroprotective role of cannabinoids against pain and neurodegenerative diseases has been extensively demonstrated [165]. Moreover, the endocannabinoid system seems to play an important role on inflammation and nociception with analgesic effects in numerous pain conditions, frequently in hyperalgesic and inflammatory states [165]. In inflammatory hyperalgesia, CB2 receptors localized on mast and immune cells could possibly achieve pain inhibition by the reduction of prostanoids or cytokines release, which are responsible for peripheral nociceptor sensitization [7]. This evidence is of particular relevance, since, as we already mentioned, CB2 receptors can be activated by BCP binding. Indeed, several studies demonstrated the efficacy of BCP to treat neuropathies and pain [21,73].

Due to its lipophilicity, BCP easily penetrates cell membranes, while still presenting good oral bioavailability and a very large therapeutic window, with an oral 50\% lethal dose $\left(\mathrm{LD}_{50}\right)$ of more than $5000 \mathrm{mg} / \mathrm{kg}$ in rats [7]. Significant and dose-dependent antinociceptive response was produced by BCP without the presence of gastric damage [166]. Antiallodynic actions of BCP are exerted only through activation of local peripheral CB2 [7]. In neuropathic pain models, BCP reduced spinal neuroinflammation and the oral administration was more effective than the subcutaneously injected synthetic CB2 agonist JWH-133. Thus, BCP may be highly effective in the treatment of long-lasting, debilitating pain states [167]. BCP also prevents nucleoside reverse transcriptase inhibitors-induced mechanical allodynia, possibly via reducing the inflammatory response, and attenuates mechanical allodynia through CB2 receptor activation [73]. BCP induces decrement in expression of COX-2 and iNOS, which could suppress NF- $\mathrm{KB}$ activation and as a consequence promote analgesia [168]. Recently, BCP was found to attenuate mechanical allodynia induced by paclitaxel, a drug used in chemotherapy, in a CB2-dependent manner. Moreover, BCP was able to attenuate the development of paclitaxel-induced peripheral neuropathy by reducing mitogen-activated protein kinases (p38MAPK) and NF-kB activation and increased ionized calcium-binding adaptor molecule-1 (Iba-1) and IL-1 $\beta$ immunoreactivity promoted by paclitaxel [169].

Interestingly, BCP can diminish acute and chronic pain not only through the endocannabinoid system, but also through the opioid system [21]. This latter mechanism involves the participation of benzodiazepine and serotonin 1A (5-HT1A) receptors, as well as nitric oxide [170]. BCP is able to indirectly activate the opioid system through $\beta$-endorphin release, which in turn activates $\mu$-opioid receptors on primary afferent neurons [166]. The role of the opioid system is further demonstrated by blockade with naloxone, resulting in the abolishment of BCP analgesic effects in acute and chronic pain models [171].

The degeneration of axons is a critical event in many neurodegenerative conditions including stroke, glaucoma, motor neuropathies, amyotrophic lateral sclerosis (ALS), Alzheimer's, Parkinson's 
and Huntington's diseases $[172,173]$. BCP could have a beneficial role in inducing neuritogenesis through the activation of tropomyosin receptor kinase A (TrkA) receptors by a mechanism independent of nerve growth factor (NGF) or cannabinoid receptors [5].

Parkinson's disease (PD) is a long-term neurodegenerative disorder characterized by progressive dopaminergic neurons loss in the substantia nigra pars compacta (SNc). Treatment of mice with BCP rescued dopaminergic neurons and decreased microglia and astrocyte activation, as evidenced by reduced levels of Iba- 1 and glial fibrillary acidic protein (GFAP) expression [6]. BCP, in addition to attenuation of pro-inflammatory cytokines and inflammatory mediators such as COX-2 and iNOS, also restored antioxidant enzymes and inhibited lipid peroxidation as well as glutathione depletion [174]. $\mathrm{BCP}$ acts via multiple neuroprotective mechanisms in murine models, thus it may be viewed as a potential treatment and/or preventative agent for PD [175].

Administration of $\mathrm{BCP}$ protects against cerebral ischemic injury in rats and reduces astrogliosis and microglial activation in a transgenic mouse model of Alzheimer's disease [89].

A beneficial effect of BCP was also found for multiple sclerosis, also known as encephalomyelitis disseminata, the most common inflammatory and demyelinating autoimmune disease of the central nervous system. BCP reduced the clinical score and severity of experimental autoimmune encephalomyelitis and inhibited $\mathrm{H}_{2} \mathrm{O}_{2}, \mathrm{NO}, \mathrm{TNF}-\alpha$, interferon- $\gamma$ (IFN- $\gamma$ ), and IL-17 production. Moreover, $\mathrm{BCP}$ treatment significantly reduced the numbers of inflammatory infiltrates and attenuated neurological damages in the CNS of experimental autoimmune encephalomyelitis mice [176].

Epilepsy is a neurological disease, and recurrent epileptic seizures and behavioral comorbidities such as depression, anxiety, psychosis, and cognitive deficits largely affect the quality of life of the patients with epilepsy and their families [177]. BCP was found to display anticonvulsant activity against seizures induced by pentylenetetrazole in mice. Since no adverse effects were observed when BCP was administered at the concentration of $100 \mathrm{mg} / \mathrm{kg}$ b.w., and because of the lack of genotoxicity [178], this compound was considered a potential new anticonvulsant drugs [179]. Moreover, BCP was clinically useful as an adjunct treatment against seizure spread and status epilepticus and concomitant oxidative stress, neurotoxicity and cognitive impairments [180].

As a summary of the experimental evidence reported in this review, Figure 2 schematizes the major currently known positive effects of $\mathrm{BCP}$ on metabolic and neurological disorders. 


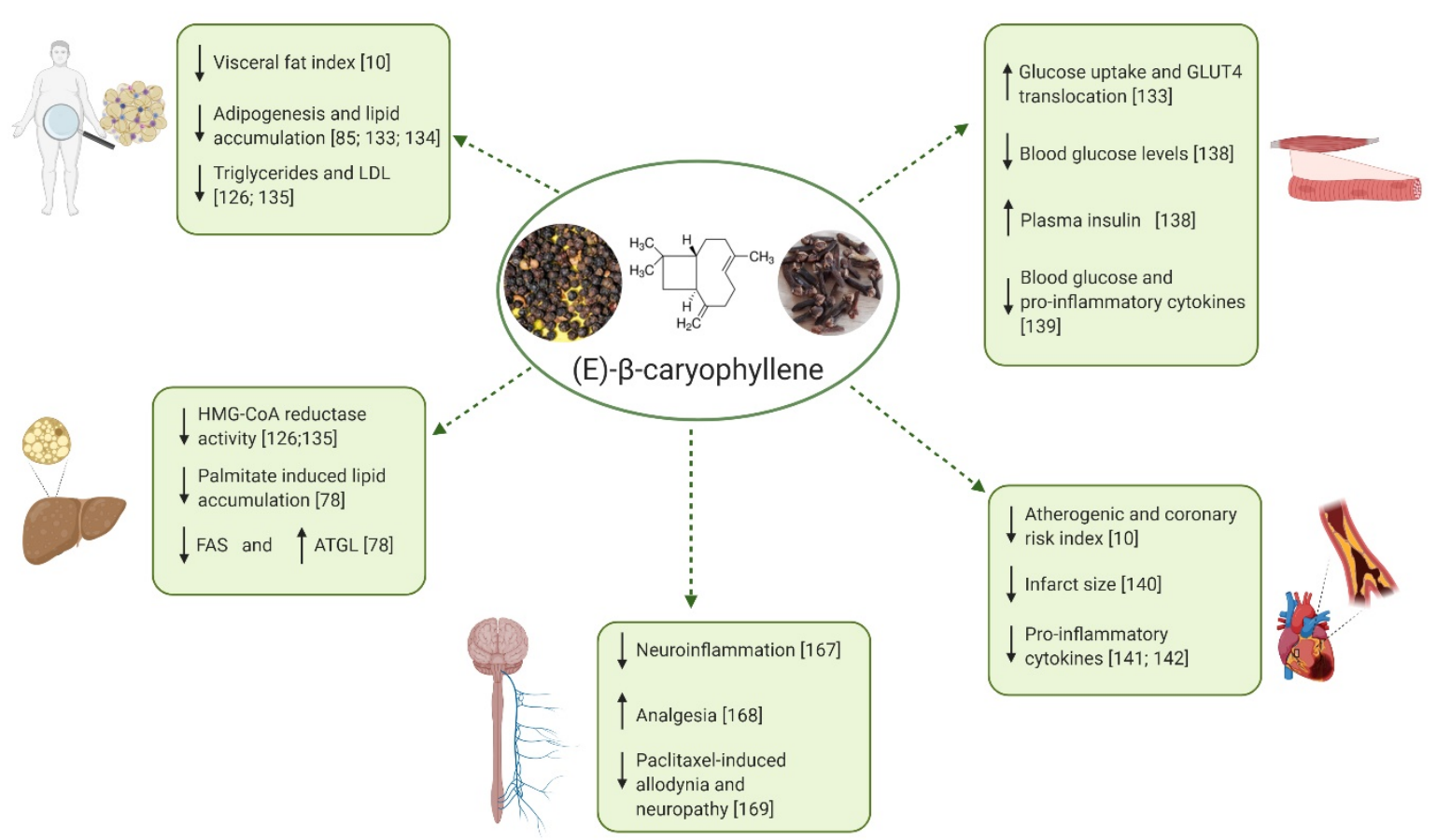

Figure 2. Positive effects of BCP on metabolic and neurological disorders. Scheme created with BioRender.com. $\downarrow$ : reduction; $\uparrow:$ increase; LDL: Low density lipoproteins; HMG-CoA: Hydroxy methylglutaryl-Coenzyme A; FAS: fatty acid synthase; ATGL: adipose triglyceride lipase; GLUT4: glucose transporter 4 .

\section{Conclusions}

The bicyclic sesquiterpene $\mathrm{BCP}$ is a natural compound widely present in the plant kingdom and obtained in high concentrations from the essential oils of several plants. As a secondary metabolite, particularly present in both vegetative and reproductive parts, $\mathrm{BCP}$ is primarily involved in plant defense and attraction. Recent studies outlined a protective role of $\mathrm{BCP}$ also in animal cells, underlining its beneficial effects against many diseases. These results have been summarized in previous reviews; the present review specifically focused on $\mathrm{BCP}$ action on diseases characterized by chronic inflammation.

Chronic inflammation is a common theme of many metabolic and neurologic disorders. The definition of new therapeutic approaches based on natural compounds could represent a promising way to complement, or even replace, currently administered drugs. The data accumulated so far both in in vivo and in vitro studies show that BCP is a good candidate in the treatment of chronic inflammation due to its specific molecular targets and very low toxicity. In fact, it is now widely accepted that this sesquiterpene acts on several molecular pathways implicated in the generation of inflammatory states and is able to reduce several pro-inflammatory mediators, including IL-1 $\beta$, IL-6, TNF- $\alpha$, NF-kB. The molecular mechanisms underlying BCP effects are only beginning to be unraveled. The available data suggest that $\mathrm{BCP}$ is able to exert its potent anti-inflammatory effects through multiple mechanisms mostly initiated by the binding of BCP to CB2 receptors. Subsequent steps likely depend on the cell type and grade of the inflammatory state. Recently, BCP activation of PPARs, a class of nuclear receptors involved both in metabolic and inflammatory responses, has been clearly demonstrated. Direct binding of BCP has been shown only for PPAR $\alpha$, while available data suggest CB2-mediated PPAR $\gamma$ activation. Further clarification of the molecular details involved in this receptor-cross-talk will strengthen the possible therapeutic use of $\mathrm{BCP}$.

Although further studies are needed to better define the systemic effects of BCP in animals, the promising results obtained so far in preclinical studies on models of metabolic and neurologic disorders strongly suggest that BCP constitute an attractive molecule for the treatment of diseases characterized by chronic inflammation. 
Author Contributions: M.E.M. and P.B. conceptualized the manuscript; R.S., F.G., E.C., G.Q. drafted the manuscript; R.S., F.G., G.Q. and M.E.M. prepared the figures and table; E.C., S.A., M.P.G., M.E.M. and P.B. revised and edited the manuscript; P.B. supervised the manuscript preparation. All authors have read and agreed to the published version of the manuscript.

Funding: This work was supported by the local funding of the University of Turin and by "Fondazione Cassa di Risparmio di Torino" (Erogazioni Ordinarie 2018, grant number ID 61356).

Conflicts of Interest: The authors declare no conflict of interest. The funders had no role in the conceptualization and writing of the manuscript.

\section{References}

1. Waltenberger, B.; Mocan, A.; Šmejkal, K.; Heiss, E.H.; Atanasov, A.G. Natural products to counteract the epidemic of cardiovascular and metabolic disorders. Molecules 2016, 21, 807. [CrossRef] [PubMed]

2. Amirkia, V.; Heinrich, M. Natural products and drug discovery: A survey of stakeholders in industry and academia. Front. Pharmacol. 2015, 6, 237. [CrossRef] [PubMed]

3. Cefalu, W.; Ye, J.; Wang, Z. Efficacy of dietary supplementation with botanicals on carbohydrate metabolism in humans. Endocr. Metab. Immune Disord. Targets 2008, 8, 78-81. [CrossRef] [PubMed]

4. David, B.; Wolfender, J.L.; Dias, D.A. The pharmaceutical industry and natural products: Historical status and new trends. Phytochem. Rev. 2015, 14, 299-315. [CrossRef]

5. Francomano, F.; Caruso, A.; Barbarossa, A.; Fazio, A.; La Torre, C.; Ceramella, J.; Mallamaci, R.; Saturnino, C.; Iacopetta, D.; Sinicropi, M.S. $\beta$-caryophyllene: A sesquiterpene with countless biological properties. Appl. Sci. 2019, 9, 5420. [CrossRef]

6. Machado, K.D.C.; Islam, M.T.; Ali, E.S.; Rouf, R.; Uddin, S.J.; Dev, S.; Shilpi, J.A.; Shill, M.C.; Reza, H.M.; Das, A.K.; et al. A systematic review on the neuroprotective perspectives of beta-caryophyllene. Phyther. Res. 2018, 32, 2376-2388. [CrossRef] [PubMed]

7. Fidyt, K.; Fiedorowicz, A.; Strządała, L.; Szumny, A. B-Caryophyllene and B-Caryophyllene Oxide-Natural compounds of anticancer and analgesic properties. Cancer Med. 2016, 5, 3007-3017. [CrossRef] [PubMed]

8. Sut, S.; Maggi, F.; Nicoletti, M.; Baldan, V.; Dall'Acqua, S. New drugs from old natural compounds: Scarcely investigated sesquiterpenes as new possible therapeutic agents. Curr. Med. Chem. 2017, 25, 1241-1258. [CrossRef]

9. Sharma, C.; Al Kaabi, J.M.; Nurulain, S.N.; Goyal, S.; Amjad Kamal, M.; Ojha, S. Polypharmacological properties and therapeutic potential of $\beta$-caryophyllene: A dietary phytocannabinoid of pharmaceutical promise. Curr. Pharm. Des. 2016, 22, 3237-3264. [CrossRef] [PubMed]

10. Youssef, D.A.; El-Fayoumi, H.M.; Mahmoud, M.F. Beta-caryophyllene protects against diet-induced dyslipidemia and vascular inflammation in rats: Involvement of CB2 and PPAR- $\gamma$ receptors. Chem. Biol. Interact. 2019, 297, 16-24. [CrossRef]

11. Calleja, M.A.; Vieites, J.M.; Montero-Meterdez, T.; Torres, M.I.; Faus, M.J.; Gil, A.; Suárez, A. The antioxidant effect of $\beta$-caryophyllene protects rat liver from carbon tetrachloride-induced fibrosis by inhibiting hepatic stellate cell activation. Br. J. Nutr. 2013, 109, 394-401. [CrossRef]

12. Horváth, B.; Mukhopadhyay, P.; Kechrid, M.; Patel, V.; Tanchian, G.; Wink, D.A.; Gertsch, J.; Pacher, P. $\beta$-caryophyllene ameliorates cisplatin-induced nephrotoxicity in a cannabinoid 2 receptor-dependent manner. Free Radic. Biol. Med. 2012, 52, 1325-1333. [CrossRef] [PubMed]

13. Javed, H.; Azimullah, S.; Haque, M.E.; Ojha, S.K. Cannabinoid type 2 (CB2) receptors activation protects against oxidative stress and neuroinflammation associated dopaminergic neurodegeneration in rotenone model of Parkinson's disease. Front. Neurosci. 2016, 10, 321. [CrossRef] [PubMed]

14. Picciolo, G.; Pallio, G.; Altavilla, D.; Vaccaro, M.; Oteri, G.; Irrera, N.; Squadrito, F. $\beta$-Caryophyllene reduces the inflammatory phenotype of periodontal cells by targeting CB2 receptors. Biomedicines 2020, 8, 164. [CrossRef] [PubMed]

15. Legault, J.; Pichette, A. Potentiating effect of $\beta$-caryophyllene on anticancer activity of $\alpha$-humulene, isocaryophyllene and paclitaxel. J. Pharm. Pharmacol. 2007, 59, 1643-1647. [CrossRef]

16. Gertsch, J.; Leonti, M.; Raduner, S.; Racz, I.; Chen, J.Z.; Xie, X.Q.; Altmann, K.H.; Karsak, M.; Zimmer, A. Beta-caryophyllene is a dietary cannabinoid. Proc. Natl. Acad. Sci. USA 2008, 105, 9099-9104. [CrossRef]

17. Gatta-Cherifi, B.; Cota, D. Endocannabinoids and metabolic disorders. Handb. Exp. Pharmacol. 2015, 231, 367-391. [CrossRef] [PubMed] 
18. Turcotte, C.; Chouinard, F.; Lefebvre, J.S.; Flamand, N. Regulation of inflammation by cannabinoids, the endocannabinoids 2-arachidonoyl-glycerol and arachidonoyl-ethanolamide, and their metabolites. J. Leukoc. Biol. 2015, 97, 1049-1070. [CrossRef]

19. Mlost, J.; Wasik, A.; Starowicz, K. Role of endocannabinoid system in dopamine signalling within the reward circuits affected by chronic pain. Pharmacol. Res. 2019, 143, 40-47. [CrossRef]

20. Leweke, F.M.; Mueller, J.K.; Lange, B.; Fritze, S.; Topor, C.E.; Koethe, D.; Rohleder, C. Role of the endocannabinoid system in the pathophysiology of schizophrenia: Implications for pharmacological intervention. CNS Drugs 2018, 32, 605-619. [CrossRef]

21. Paula-Freire, L.I.G.; Andersen, M.L.; Gama, V.S.; Molska, G.R.; Carlini, E.L.A. The oral administration of trans-caryophyllene attenuates acute and chronic pain in mice. Phytomedicine 2014, 21, 356-362. [CrossRef]

22. Irrera, N.; D’ascola, A.; Pallio, G.; Bitto, A.; Mazzon, E.; Mannino, F.; Squadrito, V.; Arcoraci, V.; Minutoli, L.; Campo, G.M.; et al. $\beta$-Caryophyllene mitigates collagen antibody induced arthritis (CAIA) in mice through a cross-talk between CB2 and PPAR- $\gamma$ receptors. Biomolecules 2019, 9, 326. [CrossRef] [PubMed]

23. Wu, C.; Jia, Y.; Lee, J.H.; Jun, H.J.; Lee, H.S.; Hwang, K.Y.; Lee, S.J. Trans-Caryophyllene is a natural agonistic ligand for peroxisome proliferator-activated receptor- $\alpha$. Bioorg. Med. Chem. Lett. 2014, 24, 3168-3174. [CrossRef]

24. Johnson, S.A.; Rodriguez, D.; Allred, K. A systematic review of essential oils and the endocannabinoid system: A connection worthy of further exploration. Evid. Complement. Altern. Med. 2020, 2020, 8035301. [CrossRef]

25. Gonçalves, E.C.D.; Baldasso, G.M.; Bicca, M.A.; Paes, R.S.; Capasso, R.; Dutra, R.C. erpenoids, cannabimimetic ligands, beyond the cannabis plant. Molecules 2020, 25, 1567. [CrossRef] [PubMed]

26. Tetali, S.D. Terpenes and isoprenoids: A wealth of compounds for global use. Planta 2019, 249, 1-8. [CrossRef] [PubMed]

27. Knudsen, J.T.; Eriksson, R.; Gershenzon, J. Diversity and Distribution of Floral Scent. Bot. Rev. 2006, $72,1$. [CrossRef]

28. Maffei, M.E. Plant natural sources of the endocannabinoid (E)- $\beta$-caryophyllene: A systematic quantitative analysis of published literature. Int. J. Mol. Sci. 2020, 21, 6540. [CrossRef]

29. Martins, C.; Rueff, J.; Rodrigues, A.S. Genotoxic alkenylbenzene flavourings, a contribution to risk assessment. Food Chem. Toxicol. 2018, 118, 861-879. [CrossRef]

30. Larionov, O.V.; Corey, E.J. An unconventional approach to the enantioselective synthesis of caryophylloids. J. Am. Chem. Soc. 2008, 130, 2954-2955. [CrossRef]

31. Yang, J.; Li, Z.; Guo, L.; Du, J.; Bae, H.J. Biosynthesis of $\beta$-caryophyllene, a novel terpene-based high-density biofuel precursor, using engineered Escherichia coli. Renew. Energy 2016, 99, 216-223. [CrossRef]

32. Maffei, M.E. Plant Bioactive Molecules; Cambridge Scholars Publishing: New Castle upon Tyne, UK, 2018; ISBN 978-1-5275-1314-3.

33. Hemmerlin, A.; Hoeffler, J.F.; Meyer, O.; Tritsch, D.; Kagan, I.A.; Grosdemange-Billiard, C.; Rohmer, M.; Bach, T.J. Cross-talk between the cytosolic mevalonate and the plastidial methylerythritol phosphate pathways in tobacco bright yellow-2 cells. J. Biol. Chem. 2003, 278, 26666-26676. [CrossRef]

34. Despinasse, Y.; Fiorucci, S.; Antonczak, S.; Moja, S.; Bony, A.; Nicolè, F.; Baudino, S.; Magnard, J.L.; Jullien, F. Bornyl-diphosphate synthase from Lavandula angustifolia: A major monoterpene synthase involved in essential oil quality. Phytochemistry 2017, 137, 24-33. [CrossRef] [PubMed]

35. Huang, M.; Sanchez-Moreiras, A.M.; Abel, C.; Sohrabi, R.; Lee, S.; Gershenzon, J.; Tholl, D. The major volatile organic compound emitted from Arabidopsis thaliana flowers, the sesquiterpene (E)- $\beta$-caryophyllene, is a defense against a bacterial pathogen. New Phytol. 2012, 193, 997-1008. [CrossRef]

36. He, S.M.; Wang, X.; Yang, S.C.; Dong, Y.; Zhao, Q.M.; Yang, J.L.; Cong, K.; Zhang, J.J.; Zhang, G.H.; Wang, Y.; et al. De novo transcriptome characterization of rhodomyrtus tomentosa leaves and identification of genes involved in $\alpha / \beta$-pinene and $\beta$-caryophyllene biosynthesis. Front. Plant Sci. 2018, 9, 1231. [CrossRef]

37. Bohlmann, J.; Meyer-Gauen, G.; Croteau, R. Plant terpenoid synthases: Molecular biology and phylogenetic analysis. Proc. Natl. Acad. Sci. USA 1998, 95, 4126-4133. [CrossRef]

38. Rynkiewicz, M.J.; Cane, D.E.; Christianson, D.W. Structure of trichodiene synthase from Fusarium sporotrichioides provides mechanistic inferences on the terpene cyclization cascade. Proc. Natl. Acad. Sci. USA 2001, 98, 13543-13548. [CrossRef] 
39. Degenhardt, J.; Köllner, T.G.; Gershenzon, J. Monoterpene and sesquiterpene synthases and the origin of terpene skeletal diversity in plants. Phytochemistry 2009, 70, 1621-1637. [CrossRef] [PubMed]

40. Williams, D.C.; McGarvey, D.J.; Katahira, E.J.; Croteau, R. Truncation of limonene synthase preprotein provides a fully active "pseudomature" form of this monoterpene cyclase and reveals the function of the amino-terminal arginine pair. Biochemistry 1998, 37, 12213-12220. [CrossRef] [PubMed]

41. Starks, C.M.; Back, K.; Chappell, J.; Noel, J.P. Structural basis for cyclic terpene biosynthesis by tobacco 5-epiaristolochene synthase. Science 1997, 277, 1815-1820. [CrossRef]

42. Yang, C.Q.; Wu, X.M.; Ruan, J.X.; Hu, W.L.; Mao, Y.B.; Chen, X.Y.; Wang, L.J. Isolation and characterization of terpene synthases in cotton (Gossypium hirsutum). Phytochemistry 2013, 96, 46-56. [CrossRef] [PubMed]

43. Huang, X.; Xiao, Y.; Köllner, T.G.; Zhang, W.; Wu, J.; Wu, J.; Guo, Y.; Zhang, Y. Identification and characterization of (E)- $\beta$-caryophyllene synthase and $\alpha / \beta$-pinene synthase potentially involved in constitutive and herbivore-induced terpene formation in cotton. Plant Physiol. Biochem. 2013, 73, 302-308. [CrossRef]

44. Stefan, G.A.; Massimo, G.; Ma, V.; Bossi, S.; Schulze, B.; Leitner, M.; Mithöfer, A.; Boland, W. Herbivore-induced terpenoid emission in Medicago truncatula: Concerted action of jasmonate, ethylene and calcium signaling. Planta 2008, 453-464. [CrossRef]

45. Martin, D.M.; Aubourg, S.; Schouwey, M.B.; Daviet, L.; Schalk, M.; Toub, O.; Lund, S.T.; Bohlmann, J. Functional annotation, genome organization and phylogeny of the grapevine (Vitis vinifera) terpene synthase gene family based on genome assembly, FLcDNA cloning, and enzyme assays. BMC Plant Biol. 2010, 10, 226. [CrossRef] [PubMed]

46. Matarese, F.; Cuzzola, A.; Scalabrelli, G.; D'Onofrio, C. Expression of terpene synthase genes associated with the formation of volatiles in different organs of Vitis vinifera. Phytochemistry 2014, 105, 12-24. [CrossRef] [PubMed]

47. Salvagnin, U.; Carlin, S.; Angeli, S.; Vrhovsek, U.; Anfora, G.; Malnoy, M.; Martens, S. Homologous and heterologous expression of grapevine E-( $\beta$ )-caryophyllene synthase (VvGwECar2). Phytochemistry 2016, 131, 76-83. [CrossRef] [PubMed]

48. Chen, H.; Li, G.; Köllner, T.G.; Jia, Q.; Gershenzon, J.; Chen, F. Positive Darwinian selection is a driving force for the diversification of terpenoid biosynthesis in the genus Oryza. BMC Plant Biol. 2014, 14, 1-12. [CrossRef]

49. Ruilong, W.; Shaolin, P.; Rensen, Z.; Ling, W.D.; Zengfu, X.U. Cloning, expression and wounding induction of $\beta$-caryophyllene synthase gene from Mikania micrantha H.B.K. and allelopathic potential of $\beta$-caryophyllene. Allelopath. J. 2009, 24, 35-44.

50. Wang, R.L.; Staehelin, C.; Peng, S.L.; Wang, W.T.; Xie, X.M.; Lu, H.N. Responses of Mikania micrantha, an invasive weed to elevated $\mathrm{CO} 2$ : Induction of $\beta$-caryophyllene synthase, changes in emission capability and allelopathic potential of $\beta$-caryophyllene. J. Chem. Ecol. 2010, 36, 1076-1082. [CrossRef]

51. Fujita, Y.; Koeduka, T.; Aida, M.; Suzuki, H.; Iijima, Y.; Matsui, K. Biosynthesis of volatile terpenes that accumulate in the secretory cavities of young leaves of Japanese pepper (Zanthoxylum piperitum): Isolation and functional characterization of monoterpene and sesquiterpene synthase genes. Plant Biotechnol. 2017, 34, 17-28. [CrossRef]

52. Chen, F.; Tholl, D.; D'Auria, J.C.; Farooq, A.; Pichersky, E.; Gershenzon, J. Biosynthesis and emission of terpenoid volatiles from Arabidopsis flowers. Plant Cell 2003, 15, 481-494. [CrossRef] [PubMed]

53. Hong, G.J.; Xue, X.Y.; Mao, Y.B.; Wang, L.J.; Chen, X.Y. Arabidopsis MYC2 interacts with DELLA proteins in regulating sesquiterpene synthase gene expression. Plant Cell 2012, 24, 2635-2648. [CrossRef] [PubMed]

54. Chuang, L.; Wen, C.H.; Lee, Y.R.; Lin, Y.L.; Hsu, L.R.; Wang, S.Y.; Chu, F.H. Identification, functional characterization, and seasonal expression patterns of five sesquiterpene synthases in Liquidambar formosana. J. Nat. Prod. 2018, 81, 1162-1172. [CrossRef]

55. Cai, Y.; Jia, J.W.; Crock, J.; Lin, Z.X.; Chen, X.Y.; Croteau, R. A cDNA clone for $\beta$-caryophyllene synthase from Artemisia annua. Phytochemistry 2002, 61, 523-529. [CrossRef]

56. Köpke, D.; Beyaert, I.; Gershenzon, J.; Hilker, M.; Schmidt, A. Species-specific responses of pine sesquiterpene synthases to sawfly oviposition. Phytochemistry 2010, 71, 909-917. [CrossRef]

57. Jin, Z.; Kwon, M.; Lee, A.R.; Ro, D.K.; Wungsintaweekul, J.; Kim, S.U. Molecular cloning and functional characterization of three terpene synthases from unripe fruit of black pepper (Piper nigrum). Arch. Biochem. Biophys. 2018, 638, 35-40. [CrossRef] 
58. Di Marzo, V. New approaches and challenges to targeting the endocannabinoid system. Nat. Rev. Drug Discov. 2018, 17, 623-639. [CrossRef] [PubMed]

59. Shahbazi, F.; Grandi, V.; Banerjee, A.; Trant, J.F. Cannabinoids and cannabinoid receptors: The story so far. iScience 2020, 23, 101301. [CrossRef]

60. Mechoulam, R.; Gaoni, Y. A total synthesis of dl- $\Delta 1$-tetrahydrocannabinol, the active constituent of hashish. J. Am. Chem. Soc. 1965, 87, 3273-3275. [CrossRef]

61. Di Marzo, V.; Piscitelli, F. The endocannabinoid system and its modulation by phytocannabinoids. Neurotherapeutics 2015, 12, 692-698. [CrossRef]

62. Matsuda, L.A.; Lolait, S.J.; Brownstein, M.J.; Young, A.C.; Bonner, T.I. Structure of a cannabinoid receptor and functional expression of the cloned cDNA. Nature 1990, 346, 561-564. [CrossRef]

63. Munro, S.; Thomas, K.L.; Abu-Shaar, M. Molecular characterization of a peripheral receptor for cannabinoids. Nature 1993, 365, 61-65. [CrossRef] [PubMed]

64. Shao, Z.; Yin, J.; Chapman, K.; Grzemska, M.; Clark, L.; Wang, J.; Rosenbaum, D.M. High-resolution crystal structure of the human CB1 cannabinoid receptor. Nature 2016, 540, 602-606. [CrossRef]

65. Pertwee, R.G. Endocannabinoids and their pharmacological actions. Handb. Exp. Pharmacol. 2015, 231, 1-37. [CrossRef]

66. Busquets-Garcia, A.; Bains, J.; Marsicano, G. CB 1 receptor signaling in the brain: Extracting specificity from ubiquity. Neuropsychopharmacology 2018, 43, 4-20. [CrossRef]

67. Maccarrone, M.; Bab, I.; Bíró, T.; Cabral, G.A.; Dey, S.K.; Di Marzo, V.; Konje, J.C.; Kunos, G.; Mechoulam, R.; Pacher, P.; et al. Endocannabinoid signaling at the periphery: 50 years after THC. Trends Pharmacol. Sci. 2015, 36, 277-296. [CrossRef]

68. Galiègue, S.; Mary, S.; Marchand, J.; Dussossoy, D.; Carrière, D.; Carayon, P.; Bouaboula, M.; Shire, D.; LE Fur, G.; Casellas, P. Expression of central and peripheral cannabinoid receptors in human immune tissues and leukocyte subpopulations. Eur. J. Biochem. 1995, 232, 54-61. [CrossRef]

69. Gong, J.P.; Onaivi, E.S.; Ishiguro, H.; Liu, Q.R.; Tagliaferro, P.A.; Brusco, A.; Uhl, G.R. Cannabinoid CB2 receptors: Immunohistochemical localization in rat brain. Brain Res. 2006, 1071, 10-23. [CrossRef] [PubMed]

70. Aymerich, M.S.; Aso, E.; Abellanas, M.A.; Tolon, R.M.; Ramos, J.A.; Ferrer, I.; Romero, J.; Fernández-Ruiz, J. Cannabinoid pharmacology/therapeutics in chronic degenerative disorders affecting the central nervous system. Biochem. Pharmacol. 2018, 157, 67-84. [CrossRef] [PubMed]

71. Irrera, N.; D’ascola, A.; Pallio, G.; Bitto, A.; Mannino, F.; Arcoraci, V.; Rottura, M.; Ieni, A.; Minutoli, L.; Metro, D.; et al. $\beta$-caryophyllene inhibits cell proliferation through a direct modulation of CB2 receptors in glioblastoma cells. Cancers 2020, 12, 1038. [CrossRef]

72. Berger, G.; Arora, N.; Burkovskiy, I.; Xia, Y.; Chinnadurai, A.; Westhofen, R.; Hagn, G.; Cox, A.; Kelly, M.; Zhou, J.; et al. Experimental cannabinoid 2 receptor activation by phyto-derived and synthetic cannabinoid ligands in LPS-Induced interstitial cystitis in mice. Molecules 2019, 24, 4239. [CrossRef]

73. Aly, E.; Khajah, M.A.; Masocha, W. $\beta$-caryophyllene, a CB2-receptor-selective phytocannabinoid, suppresses mechanical allodynia in a mouse model of antiretroviral-induced neuropathic pain. Molecules 2020, 25, 106. [CrossRef] [PubMed]

74. Hong, F.; Pan, S.; Guo, Y.; Xu, P.; Zhai, Y. PPARs as nuclear receptors for nutrient and energy metabolism. Molecules 2019, 24, 2545. [CrossRef] [PubMed]

75. Lalwani, N.D.; Fahl, W.E.; Reddy, J.K. Detection of a nafenopin-binding protein in rat liver cytosol associated with the induction of peroxisome proliferation by hypolipidemic compounds. Biochem. Biophys. Res. Commun. 1983, 116, 388-393. [CrossRef]

76. Issemann, I.; Green, S. Activation of a member of the steroid hormone receptor superfamily by peroxisome proliferators. Nature 1990, 347, 645-650. [CrossRef]

77. Dreyer, C.; Krey, G.; Keller, H.; Givel, F.; Helftenbein, G.; Wahli, W. Control of the peroxisomal $\beta$-oxidation pathway by a novel family of nuclear hormone receptors. Cell 1992, 68, 879-887. [CrossRef]

78. Kamikubo, R.; Kai, K.; Tsuji-Naito, K.; Akagawa, M. $\beta$-Caryophyllene attenuates palmitate-induced lipid accumulation through AMPK signaling by activating CB2 receptor in human HepG2 hepatocytes. Mol. Nutr. Food Res. 2016, 60, 2228-2242. [CrossRef]

79. Kersten, S.; Stienstra, R. The role and regulation of the peroxisome proliferator activated receptor alpha in human liver. Biochimie 2017, 136, 75-84. [CrossRef] 
80. Corrales, P.; Izquierdo-Lahuerta, A.; Medina-Gómez, G. Maintenance of kidney metabolic homeostasis by PPAR gamma. Int. J. Mol. Sci. 2018, 19, 2063. [CrossRef]

81. Vázquez-Carrera, M. Unraveling the effects of PPAR $\beta / \delta$ on insulin resistance and cardiovascular disease. Trends Endocrinol. Metab. 2016, 27, 319-334. [CrossRef]

82. Janani, C.; Ranjitha Kumari, B.D. PPAR gamma gene-A review. Diabetes Metab. Syndr. Clin. Res. Rev. 2015, 9, 46-50. [CrossRef] [PubMed]

83. Kliewer, S.A.; Forman, B.M.; Blumberg, B.; Ong, E.S.; Borgmeyer, U.; Mangelsdorf, D.J.; Umesono, K.; Evans, R.M. Differential expression and activation of a family of murine peroxisome proliferator-activated receptors. Proc. Natl. Acad. Sci. USA 1994, 91, 7355-7359. [CrossRef] [PubMed]

84. Tontonoz, P.; Graves, R.A.; Budavari, A.I.; Erdjument-bromage, H.; Lui, M.; Hu, E.; Tempst, P.; Spiegelman, B.M. Adipocyte-specific transcription factor ARF6 is a heterodimeric complex of two nuclear hormone receptors, PPAR7 and RXRa. Nucleic Acids Res. 1994, 22, 5628-5634. [CrossRef] [PubMed]

85. Yamaguchi, M.; Levy, R.M. $\beta$-caryophyllene promotes osteoblastic mineralization, and suppresses osteoclastogenesis and adipogenesis in mouse bone marrow cultures in vitro. Exp. Ther. Med. 2016, 12,3602-3606. [CrossRef]

86. Berger, J.; Moller, D.E. The mechanisms of action of PPARs. Annu. Rev. Med. 2002, 53, 409-435. [CrossRef]

87. Viswakarma, N.; Jia, Y.; Bai, L.; Vluggens, A.; Borensztajn, J.; Xu, J.; Reddy, J.K. Coactivators in PPAR-regulated gene expression. PPAR Res. 2010, 2010, 250126. [CrossRef]

88. Bento, A.F.; Marcon, R.; Dutra, R.C.; Claudino, R.F.; Cola, M.; Leite, D.F.P.; Calixto, J.B. $\beta$-caryophyllene inhibits dextran sulfate sodium-induced colitis in mice through CB2 receptor activation and PPAR $\gamma$ pathway. Am. J. Pathol. 2011, 178, 1153-1166. [CrossRef]

89. Cheng, Y.; Dong, Z.; Liu, S. $\beta$-caryophyllene ameliorates the Alzheimer-like phenotype in APP/PS1 mice through CB2 receptor activation and the PPAR $\gamma$ pathway. Pharmacology 2014, 94, 1-12. [CrossRef]

90. Askari, V.R.; Shafiee-Nick, R. Promising neuroprotective effects of $\beta$-caryophyllene against LPS-induced oligodendrocyte toxicity: A mechanistic study. Biochem. Pharmacol. 2019, 159, 154-171. [CrossRef]

91. Youssef, D.A.; El-Fayoumi, H.M.; Mahmoud, M.F. Beta-caryophyllene alleviates diet-induced neurobehavioral changes in rats: The role of CB2 and PPAR- $\gamma$ receptors. Biomed. Pharmacother. 2019, 110, 145-154. [CrossRef]

92. Hotamisligil, G.S. Inflammation and metabolic disorders. Nature 2006, 444, 860-867. [CrossRef]

93. Wellen, K.E.; Hotamisligil, G.S. Inflammation, stress, and diabetes. J. Clin. Investig. 2005, 115, 1111-1119. [CrossRef] [PubMed]

94. Saltiel, A.R.; Olefsky, J.M. Inflammatory mechanisms linking obesity and metabolic disease. J. Clin. Investig. 2017, 127, 1-4. [CrossRef] [PubMed]

95. Arrese, M.; Cabrera, D.; Kalergis, A.M.; Feldstein, A.E. Innate immunity and inflammation in NAFLD/NASH. Dig. Dis. Sci. 2016, 61, 1294-1303. [CrossRef]

96. Joshi, N.; Singh, S. Updates on immunity and inflammation in Parkinson disease pathology. J. Neurosci. Res. 2018, 96, 379-390. [CrossRef]

97. Forloni, G.; Balducci, C. Alzheimer's disease, oligomers, and inflammation. J. Alzheimer's Dis. 2018, 62, 1261-1276. [CrossRef] [PubMed]

98. Feghali, C.A.; Wright, T.M. Cytokines in acute and chronic inflammation. Front. Biosci. 1997, 2, d12-d26. [CrossRef] [PubMed]

99. Rogero, M.M.; Calder, P.C. Obesity, inflammation, toll-like receptor 4 and fatty acids. Nutrients 2018, 10, 432. [CrossRef]

100. Villarroya, F.; Cereijo, R.; Gavaldà-Navarro, A.; Villarroya, J.; Giralt, M. Inflammation of brown/beige adipose tissues in obesity and metabolic disease. J. Intern. Med. 2018, 284, 492-504. [CrossRef]

101. Hotamisligil, G.S. Inflammation, metaflammation and immunometabolic disorders. Nature 2017, 542, 177-185. [CrossRef]

102. Ertunc, M.E.; Hotamisligil, G.S. Lipid signaling and lipotoxicity in metaflammation: Indications for metabolic disease pathogenesis and treatment. J. Lipid Res. 2016, 57, 2099-2114. [CrossRef]

103. Caputo, T.; Gilardi, F.; Desvergne, B. From chronic overnutrition to metaflammation and insulin resistance: Adipose tissue and liver contributions. FEBS Lett. 2017, 591, 3061-3088. [CrossRef] [PubMed]

104. Shapouri-Moghaddam, A.; Mohammadian, S.; Vazini, H.; Taghadosi, M.; Esmaeili, S.A.; Mardani, F.; Seifi, B.; Mohammadi, A.; Afshari, J.T.; Sahebkar, A. Macrophage plasticity, polarization, and function in health and disease. J. Cell. Physiol. 2018, 233, 6425-6440. [CrossRef] 
105. Lumeng, C.N.; Bodzin, J.L.; Saltiel, A.R. Obesity induces a phenotypic switch in adipose tissue macrophage polarization. J. Clin. Investig. 2007, 117, 175-184. [CrossRef] [PubMed]

106. Mclaughlin, T.; Ackerman, S.E.; Shen, L.; Engleman, E. Role of innate and adaptive immunity in obesity-associated metabolic disease. J. Clin. Investig. 2017, 127, 5-13. [CrossRef] [PubMed]

107. De Heredia, F.P.; Gómez-Martínez, S.; Marcos, A. Chronic and degenerative diseases: Obesity, inflammation and the immune system. Proc. Nutr. Soc. 2012, 71, 332-338. [CrossRef] [PubMed]

108. Dandona, P.; Aljada, A.; Bandyopadhyay, A. Inflammation: The link between insulin resistance, obesity and diabetes. Trends Immunol. 2004, 25, 4-7. [CrossRef]

109. Hotamisligil, G.S.; Shargill, N.S.; Spiegelman, B.M. Adipose expression of tumor necrosis factor- $\alpha$ : Direct role in obesity-linked insulin resistance. Science 1993, 259, 87-91. [CrossRef]

110. Uysal, K.T.; Wiesbrock, S.M.; Marino, M.W.; Hotamisligil, G.S. Protection from obesity-induced insulin resistance in mice lacking TNF- $\alpha$ function. Nature 1997, 389, 610-614. [CrossRef]

111. Kern, P.A.; Saghizadeh, M.; Ong, J.M.; Bosch, R.J.; Deem, R.; Simsolo, R.B. The expression of tumor necrosis factor in human adipose tissue: Regulation by obesity, weight loss, and relationship to lipoprotein lipase. J. Clin. Investig. 1995, 95, 2111-2119. [CrossRef]

112. Yu, C.; Chen, Y.; Cline, G.W.; Zhang, D.; Zong, H.; Wang, Y.; Bergeron, R.; Kim, J.K.; Cushman, S.W.; Cooney, G.J.; et al. Mechanism by which fatty acids inhibit insulin activation of insulin receptor substrate-1 (IRS-1)-associated phosphatidylinositol 3-kinase activity in muscle. J. Biol. Chem. 2002, 277, 50230-50236. [CrossRef] [PubMed]

113. Glass, C.K.; Ogawa, S. Combinatorial roles of nuclear receptors in inflammation and immunity. Nat. Rev. Immunol. 2006, 6, 44-55. [CrossRef] [PubMed]

114. Chawla, A.; Repa, J.J.; Evans, R.M.; Mangelsdorf, D.J. Nuclear receptors and lipid physiology: Opening the x-files. Science 2001, 294, 1866-1870. [CrossRef] [PubMed]

115. Fessler, M.B.; Rudel, L.L.; Brown, J.M. Toll-like receptor signaling links dietary fatty acids to the metabolic syndrome. Curr. Opin. Lipidol. 2009, 20, 379-385. [CrossRef] [PubMed]

116. Engin, A. Non-alcoholic fatty liver disease. Adv. Exp. Med. Biol. 2017, 960, 443-467. [CrossRef] [PubMed]

117. Pawlak, M.; Lefebvre, P.; Staels, B. Molecular mechanism of PPAR $\alpha$ action and its impact on lipid metabolism, inflammation and fibrosis in non-alcoholic fatty liver disease. J. Hepatol. 2015, 62, 720-733. [CrossRef]

118. Gervois, P.; Kleemann, R.; Pilon, A.; Percevault, F.; Koenig, W.; Staels, B.; Kooistra, T. Global suppression of IL-6-induced acute phase response gene expression after chronic in vivo treatment with the peroxisome proliferator-activated receptor- $\alpha$ activator fenofibrate. J. Biol. Chem. 2004, 279, 16154-16160. [CrossRef]

119. Seo, D.Y.; Heo, J.W.; Ko, J.R.; Kwak, H.B. Exercise and neuroinflammation in health and disease. Int. Neurourol. J. 2019, 23, S82-S92. [CrossRef]

120. Heindel, J.J.; Blumberg, B.; Cave, M.; Machtinger, R.; Mantovani, A.; Mendez, M.A.; Nadal, A.; Palanza, P.; Panzica, G.; Sargis, R.; et al. Metabolism disrupting chemicals and metabolic disorders. Reprod. Toxicol. 2017, 68, 3-33. [CrossRef]

121. Scotti, L.; Monteiro, A.F.M.; de Oliveira Viana, J.; Mendonça Junior, F.J.B.; Ishiki, H.M.; Tchouboun, E.N.; Santos, R.; Scotti, M.T. Multi-target drugs against metabolic disorders. Endocr. Metab. Immune Disord. Drug Targets 2018, 19, 402-418. [CrossRef]

122. van Dijk, S.J.; Tellam, R.L.; Morrison, J.L.; Muhlhausler, B.S.; Molloy, P.L. Recent developments on the role of epigenetics in obesity and metabolic disease. Clin. Epigenetics 2015, 7. [CrossRef]

123. Rochlani, Y.; Pothineni, N.V.; Kovelamudi, S.; Mehta, J.L. Metabolic syndrome: Pathophysiology, management, and modulation by natural compounds. Ther. Adv. Cardiovasc. Dis. 2017, 11, 215-225. [CrossRef] [PubMed]

124. Galassi, A.; Reynolds, K.; He, J. Metabolic syndrome and risk of cardiovascular disease: A meta-analysis. Am. J. Med. 2006, 119, 812-819. [CrossRef] [PubMed]

125. Neeland, I.J.; Poirier, P.; Després, J.P. Cardiovascular and metabolic heterogeneity of obesity: Clinical challenges and implications for management. Circulation 2018, 137, 1391-1406. [CrossRef]

126. Baldissera, M.D.; Souza, C.F.; Grando, T.H.; Doleski, P.H.; Boligon, A.A.; Stefani, L.M.; Monteiro, S.G. Hypolipidemic effect of $\beta$-caryophyllene to treat hyperlipidemic rats. Naunyn. Schmiedebergs. Arch. Pharmacol. 2017, 390, 215-223. [CrossRef]

127. Ríos, J.L.; Francini, F.; Schinella, G.R. Natural products for the treatment of type 2 diabetes mellitus. Planta Med. 2015, 81, 975-994. [CrossRef] [PubMed] 
128. Tran, N.; Pham, B.; Le, L. Bioactive compounds in anti-diabetic plants: From herbal medicine to modern drug discovery. Biology 2020, 9, 252. [CrossRef]

129. Cheng, C.; Zhuo, S.; Zhang, B.; Zhao, X.; Liu, Y.; Liao, C.; Quan, J.; Li, Z.; Bode, A.M.; Cao, Y.; et al. Treatment implications of natural compounds targeting lipid metabolism in nonalcoholic fatty liver disease, obesity and cancer. Int. J. Biol. Sci. 2019, 15, 1654-1663. [CrossRef]

130. Xu, G.; Huang, K.; Zhou, J. Hepatic AMP Kinase as a potential target for treating nonalcoholic fatty liver disease: Evidence from studies of natural products. Curr. Med. Chem. 2017, 25, 889-907. [CrossRef]

131. Kumawat, V.S.; Kaur, G. Insulinotropic and antidiabetic effects of $\beta$-caryophyllene with L-arginine in type 2 diabetic rats. J. Food Biochem. 2020, 44, e13156. [CrossRef]

132. Zheng, X.; Sun, T.; Wang, X. Activation of type 2 cannabinoid receptors (CB2R) promotes fatty acid oxidation through the SIRT1/PGC-1 $\alpha$ pathway. Biochem. Biophys. Res. Commun. 2013, 436, 377-381. [CrossRef] [PubMed]

133. Geddo, F.; Scandiffio, R.; Antoniotti, S.; Cottone, E.; Querio, G.; Maffei, M.E.; Bovolin, P.; Gallo, M.P. Pipenig ${ }^{\circledR}$-FL, a fluid extract of black pepper (Piper nigrum L.) with a high standardized content of trans- $\beta$-caryophyllene, reduces lipid accumulation in 3T3-L1 preadipocytes and improves glucose uptake in C2C12 myotubes. Nutrients 2019, 11, 2788. [CrossRef] [PubMed]

134. Jung, J.I.; Kim, E.J.; Kwon, G.T.; Jung, Y.J.; Park, T.; Kim, Y.; Yu, R.; Choi, M.-S.; Chun, H.S.; Kwon, S.-H.; et al. $\beta$-Caryophyllene potently inhibits solid tumor growth and lymph node metastasis of B16F10 melanoma cells in high-fat diet-induced obese C57BL/6N mice. Carcinogenesis 2015, 36, 1028-1039. [CrossRef] [PubMed]

135. Harb, A.A.; Bustanji, Y.K.; Abdalla, S.S. Hypocholesterolemic effect of $\beta$-caryophyllene in rats fed cholesterol and fat enriched diet. J. Clin. Biochem. Nutr. 2018, 62, 230-237. [CrossRef]

136. Arizuka, N.; Murakami, T.; Suzuki, K. The effect of $\beta$-caryophyllene on nonalcoholic steatohepatitis. J. Toxicol. Pathol. 2017, 30, 263-273. [CrossRef]

137. Ames-Sibin, A.P.; Barizão, C.L.; Castro-Ghizoni, C.V.; Silva, F.M.S.; Sá-Nakanishi, A.B.; Bracht, L.; Bersani-Amado, C.A.; Marçal-Natali, M.R.; Bracht, A.; Comar, J.F. $\beta$-Caryophyllene, the major constituent of copaiba oil, reduces systemic inflammation and oxidative stress in arthritic rats. J. Cell. Biochem. 2018, 119, 10262-10277. [CrossRef]

138. Basha, R.H.; Sankaranarayanan, C. $\beta$-Caryophyllene, a natural sesquiterpene, modulates carbohydrate metabolism in streptozotocin-induced diabetic rats. Acta Histochem. 2014, 116, 1469-1479. [CrossRef]

139. Basha, R.H.; Sankaranarayanan, C. $\beta$-Caryophyllene, a natural sesquiterpene lactone attenuates hyperglycemia mediated oxidative and inflammatory stress in experimental diabetic rats. Chem. Biol. Interact. 2016, 245, 50-58. [CrossRef]

140. Younis, N.S.; Mohamed, M.E. $\beta$-Caryophyllene as a potential protective agent against myocardial injury: The role of Toll-like receptors. Molecules 2019, 24, 1929. [CrossRef]

141. Al-Taee, H.; Azimullah, S.; Meeran, M.F.N.; Alaraj Almheiri, M.K.; Al Jasmi, R.A.; Tariq, S.; AB Khan, M.; Adeghate, E.; Ojha, S. $\beta$-caryophyllene, a dietary phytocannabinoid attenuates oxidative stress, inflammation, apoptosis and prevents structural alterations of the myocardium against doxorubicin-induced acute cardiotoxicity in rats: An in vitro and in vivo study. Eur. J. Pharmacol. 2019, 858, 172467. [CrossRef]

142. Meeran, M.F.N.; Al Taee, H.; Azimullah, S.; Tariq, S.; Adeghate, E.; Ojha, S. $\beta$-Caryophyllene, a natural bicyclic sesquiterpene attenuates doxorubicin-induced chronic cardiotoxicity via activation of myocardial cannabinoid type-2 (CB2) receptors in rats. Chem. Biol. Interact. 2019, 304, 158-167. [CrossRef] [PubMed]

143. Speakman, J.R.; O'rahilly, S. Fat: An evolving issue. Dis. Model. Mech. 2012, 5, 569-573. [CrossRef]

144. Obesity and Overweight. Available online: https://www.who.int/news-room/fact-sheets/detail/obesity-andoverweight (accessed on 20 August 2020).

145. Klop, B.; Elte, J.W.F.; Cabezas, M.C. Dyslipidemia in obesity: Mechanisms and potential targets. Nutrients 2013, 5, 1218-1240. [CrossRef] [PubMed]

146. Anderson, T.J.; Mancini, G.B.J.; Genest, J.; Grégoire, J.; Lonn, E.M.; Hegele, R.A. The new dyslipidemia guidelines: What is the debate? Can. J. Cardiol. 2015, 31, 605-612. [CrossRef] [PubMed]

147. Wickramasinghe, M.; Weaver, J.U. Lipid disorders in obesity. In Practical Guide to Obesity Medicine; Elsevier: Amsterdam, The Netherlands, 2018; pp. 99-108. [CrossRef]

148. Izaola, O.; de Luis, D.; Sajoux, I.; Domingo, J.C.; Vidal, M. Inflamación y obesidad (Lipoinflamación). Nutr. Hosp. 2015, 31, 2352-2358. [CrossRef] [PubMed] 
149. Maurizi, G.; Della Guardia, L.; Maurizi, A.; Poloni, A. Adipocytes properties and crosstalk with immune system in obesity-related inflammation. J. Cell. Physiol. 2018, 233, 88-97. [CrossRef] [PubMed]

150. Idilman, I.S.; Ozdeniz, I.; Karcaaltincaba, M. Hepatic steatosis: Etiology, patterns, and quantification. Semin. Ultrasound CT MRI 2016, 37, 501-510. [CrossRef]

151. de Alwis, N.M.W.; Day, C.P. Non-alcoholic fatty liver disease: The mist gradually clears. J. Hepatol. 2008, 48, S104-S112. [CrossRef]

152. Cruz, N.G.; Sousa, L.P.; Sousa, M.O.; Pietrani, N.T.; Fernandes, A.P.; Gomes, K.B. The linkage between inflammation and Type 2 diabetes mellitus. Diabetes Res. Clin. Pract. 2013, 99, 85-92. [CrossRef]

153. Halim, M.; Halim, A. The effects of inflammation, aging and oxidative stress on the pathogenesis of diabetes mellitus (type 2 diabetes). Diabetes Metab. Syndr. Clin. Res. Rev. 2019, 13, 1165-1172. [CrossRef]

154. Lontchi-Yimagou, E.; Sobngwi, E.; Matsha, T.E.; Kengne, A.P. Diabetes mellitus and inflammation. Curr. Diab. Rep. 2013, 13, 435-444. [CrossRef] [PubMed]

155. Calle, M.C.; Fernandez, M.L. Inflammation and type 2 diabetes. Diabetes Metab. 2012, 38, 183-191. [CrossRef] [PubMed]

156. Suijun, W.; Zhen, Y.; Ying, G.; Yanfang, W. A role for trans-caryophyllene in the moderation of insulin secretion. Biochem. Biophys. Res. Commun. 2014, 444, 451-454. [CrossRef] [PubMed]

157. Christia, P.; Frangogiannis, N.G. Targeting inflammatory pathways in myocardial infarction. Eur. J. Clin. Investig. 2013, 43, 986-995. [CrossRef] [PubMed]

158. Wong, B.W.; Meredith, A.; Lin, D.; McManus, B.M. The biological role of inflammation in atherosclerosis. Can. J. Cardiol. 2012, 28, 631-641. [CrossRef]

159. Raggi, P.; Genest, J.; Giles, J.T.; Rayner, K.J.; Dwivedi, G.; Beanlands, R.S.; Gupta, M. Role of inflammation in the pathogenesis of atherosclerosis and therapeutic interventions. Atherosclerosis 2018, 276, 98-108. [CrossRef]

160. Weber, C.; Noels, H. Atherosclerosis: Current pathogenesis and therapeutic options. Nat. Med. 2011, 17, 1410-1422. [CrossRef]

161. Scolaro, B.; Soo Jin Kim, H.; de Castro, I.A. Bioactive compounds as an alternative for drug co-therapy: Overcoming challenges in cardiovascular disease prevention. Crit. Rev. Food Sci. Nutr. 2018, 58, 958-971. [CrossRef]

162. Baldissera, M.D.; Souza, C.F.; Grando, T.H.; Stefani, L.M.; Monteiro, S.G. $\beta$-caryophyllene reduces atherogenic index and coronary risk index in hypercholesterolemic rats: The involvement of cardiac oxidative damage. Chem. Biol. Interact. 2017, 270,9-14. [CrossRef]

163. Octavia, Y.; Tocchetti, C.G.; Gabrielson, K.L.; Janssens, S.; Crijns, H.J.; Moens, A.L. Doxorubicin-induced cardiomyopathy: From molecular mechanisms to therapeutic strategies. J. Mol. Cell. Cardiol. 2012, 52, 1213-1225. [CrossRef]

164. Wong, J.J.; Côté, P.; Tricco, A.C.; Rosella, L.C. Examining the effects of low back pain and mental health symptoms on healthcare utilisation and costs: A protocol for a population-based cohort study. BMJ Open 2019, 9, e031749. [CrossRef] [PubMed]

165. Rom, S.; Persidsky, Y. Cannabinoid receptor 2: Potential role in immunomodulation and neuroinflammation. J. Neuroimmune Pharmacol. 2013, 8, 608-620. [CrossRef]

166. Ibrahim, M.M.; Porreca, F.; Lai, J.; Albrecht, P.J.; Rice, F.L.; Khodorova, A.; Davar, G.; Makriyannis, A.; Vanderah, T.W.; Mata, H.P.; et al. CB2 cannabinoid receptor activation produces antinociception by stimulating peripheral release of endogenous opioids. Proc. Natl. Acad. Sci. USA 2005, 102, 3093-3098. [CrossRef]

167. Klauke, A.L.; Racz, I.; Pradier, B.; Markert, A.; Zimmer, A.M.; Gertsch, J.; Zimmer, A. The cannabinoid CB2 receptor-selective phytocannabinoid beta-caryophyllene exerts analgesic effects in mouse models of inflammatory and neuropathic pain. Eur. Neuropsychopharmacol. 2014, 24, 608-620. [CrossRef]

168. Fernandes, E.S.; Passos, G.F.; Medeiros, R.; da Cunha, F.M.; Ferreira, J.; Campos, M.M.; Pianowski, L.F.; Calixto, J.B. Anti-inflammatory effects of compounds alpha-humulene and (-)-trans-caryophyllene isolated from the essential oil of Cordia verbenacea. Eur. J. Pharmacol. 2007, 569, 228-236. [CrossRef] [PubMed]

169. Segat, G.C.; Manjavachi, M.N.; Matias, D.O.; Passos, G.F.; Freitas, C.S.; Costa, R.; Calixto, J.B. Antiallodynic effect of $\beta$-caryophyllene on paclitaxel-induced peripheral neuropathy in mice. Neuropharmacology 2017, 125, 207-219. [CrossRef] [PubMed] 
170. Hernandez-Leon, A.; González-Trujano, M.E.; Narváez-González, F.; Pérez-Ortega, G.; Rivero-Cruz, F.; Aguilar, M.I. Role of $\beta$-caryophyllene in the antinociceptive and anti-inflammatory effects of Tagetes lucida Cav. Essential oil. Molecules 2020, 25, 675. [CrossRef]

171. Katsuyama, S.; Mizoguchi, H.; Kuwahata, H.; Komatsu, T.; Nagaoka, K.; Nakamura, H.; Bagetta, G.; Sakurada, T.; Sakurada, S. Involvement of peripheral cannabinoid and opioid receptors in $\beta$-caryophyllene-induced antinociception. Eur. J. Pain 2013, 17, 664-675. [CrossRef] [PubMed]

172. Wang, J.T.; Medress, Z.A.; Barres, B.A. Axon degeneration: Molecular mechanisms of a self-destruction pathway. J. Cell Biol. 2012, 196, 7-18. [CrossRef] [PubMed]

173. Neukomm, L.J.; Freeman, M.R. Diverse cellular and molecular modes of axon degeneration. Trends Cell Biol. 2014, S24, 515-523. [CrossRef]

174. Ojha, S.; Javed, H.; Azimullah, S.; Haque, M.E. $\beta$-Caryophyllene, a phytocannabinoid attenuates oxidative stress, neuroinflammation, glial activation, and salvages dopaminergic neurons in a rat model of Parkinson disease. Mol. Cell. Biochem. 2016, 418, 59-70. [CrossRef] [PubMed]

175. Viveros-Paredes, J.M.; González-Castañeda, R.E.; Gertsch, J.; Chaparro-Huerta, V.; López-Roa, R.I.; Vázquez-Valls, E.; Beas-Zarate, C.; Camins-Espuny, A.; Flores-Soto, M.E. Neuroprotective Effects of $\beta$-caryophyllene against dopaminergic neuron injury in a murine model of Parkinson's disease induced by MPTP. Pharmaceuticals 2017, 10, 60. [CrossRef]

176. Fontes, L.B.A.; Dias, D.D.S.; Aarestrup, B.J.V.; Aarestrup, F.M.; Da Silva Filho, A.A.; do Corrêa, J.O.A. $\beta$-Caryophyllene ameliorates the development of experimental autoimmune encephalomyelitis in C57BL/6 mice. Biomed. Pharmacother. 2017, 91, 257-264. [CrossRef] [PubMed]

177. Fisher, R.S.; Van Emde Boas, W.; Blume, W.; Elger, C.; Genton, P.; Lee, P.; Engel, J. Response: Definitions proposed by the International League Against Epilepsy (ILAE) and the International Bureau for Epilepsy (IBE). Epilepsia 2005, 46, 1701-1702. [CrossRef]

178. Álvarez-González, I.; Madrigal-Bujaidar, E.; Castro-García, S. Antigenotoxic capacity of beta-caryophyllene in mouse, and evaluation of its antioxidant and GST induction activities. J. Toxicol. Sci. 2014, 39, 849-859. [CrossRef]

179. De Oliveira, C.C.; de Oliveira, C.V.; Grigoletto, J.; Ribeiro, L.R.; Funck, V.R.; Grauncke, A.C.B.; de Souza, T.L.; Souto, N.S.; Furian, A.F.; Menezes, I.R.A.; et al. Anticonvulsant activity of $\beta$-caryophyllene against pentylenetetrazol-induced seizures. Epilepsy Behav. 2016, 56, 26-31. [CrossRef]

180. Tchekalarova, J.; da Conceição Machado, K.; Gomes Júnior, A.L.; de Carvalho Melo Cavalcante, A.A.; Momchilova, A.; Tzoneva, R. Pharmacological characterization of the cannabinoid receptor 2 agonist, $\beta$-caryophyllene on seizure models in mice. Seizure 2018, 57, 22-26. [CrossRef]

Publisher's Note: MDPI stays neutral with regard to jurisdictional claims in published maps and institutional affiliations.

(C) 2020 by the authors. Licensee MDPI, Basel, Switzerland. This article is an open access article distributed under the terms and conditions of the Creative Commons Attribution (CC BY) license (http://creativecommons.org/licenses/by/4.0/). 